\title{
CXCL12 protects pancreatic $\beta$-cells from oxidative stress by a Nrf2-induced increase in catalase expression and activity
}

\author{
By Svetlana Dinić, ${ }^{* 1}$ Nevena GRdović, ${ }^{* 1}$ Aleksandra Uskoković, ${ }^{* 1}$ Miloš ĐorĐević, ${ }^{* 1}$ \\ Mirjana Mihailović, ${ }^{* 1}$ Jelena Arambašić Jovanović, ${ }^{* 1}$ \\ Goran POZNANOVIĆ ${ }^{* 1}$ and Melita VIDAKOVIĆ ${ }^{* 1, \dagger}$ \\ (Communicated by Shigetada NAKANISHI, M.J.A.)
}

\begin{abstract}
Due to intrinsically low levels of antioxidant enzyme expression and activity, insulin producing pancreatic $\beta$-cells are particularly susceptible to free radical attack. In diabetes mellitus, which is accompanied by high levels of oxidative stress, this feature of $\beta$-cells significantly contributes to their damage and dysfunction. In light of the documented pro-survival effect of chemokine C-X-C Ligand 12 (CXCL12) on pancreatic $\beta$-cells, we examined its potential role in antioxidant protection. We report that CXCL12 overexpression enhanced the resistance of rat insulinoma (Rin-5F) and primary pancreatic islet cells to hydrogen peroxide $\left(\mathrm{H}_{2} \mathrm{O}_{2}\right)$. CXCL12 lowered the levels of DNA damage and lipid peroxidation and preserved insulin expression. This effect was mediated through an increase in catalase (CAT) activity. By activating downstream p38, Akt and ERK kinases, CXCL12 facilitated Nrf2 nuclear translocation and enhanced its binding to the CAT gene promoter, inducing constitutive CAT expression and activity that was essential for protecting $\beta$-cells from $\mathrm{H}_{2} \mathrm{O}_{2}$.
\end{abstract}

Keywords: CXCL12, catalase, pancreatic $\beta$-cells, Nrf2, $\mathrm{H}_{2} \mathrm{O}_{2}$ treatment

\section{Introduction}

Oxidative stress is a major contributor to insulin producing pancreatic $\beta$-cell damage and dysfunction in diabetes mellitus. Elevated concentrations of reactive oxygen species (ROS) (which include the superoxide anion $\left(\mathrm{O}_{2}^{-}\right)$, hydroxyl radical $(\bullet \mathrm{OH})$, hydrogen peroxide $\left.\left(\mathrm{H}_{2} \mathrm{O}_{2}\right)\right)$, and reactive nitrogen species (RNS) (which include nitric oxide radical $\left(\mathrm{NO}^{\bullet}\right)$ and peroxynitrite $\left.\left(\mathrm{ONOO}^{-}\right)\right)$are observed in systemic oxidative stress that accompanies both diabetes types 1 and 2.1) Pancreatic $\beta$-cells are at greater risk of oxidative damage than other tissues due to the intrinsically low levels of activities of

*1 Department of Molecular Biology, Institute for Biological Research, University of Belgrade, Belgrade, Serbia.

$\dagger$ Correspondence should be addressed: M. Vidaković, Department of Molecular Biology, Institute for Biological Research, University of Belgrade, Bulevar despota Stefana 142, 11060 Belgrade, Serbia (e-mail: melita@ibiss.bg.ac.rs).

Abbreviations: Sp1: Specificity protein 1; $\mathrm{C} / \mathrm{EBP} \beta$ : CCAAT enhancer-binding protein beta; STAT3: Signal Transducers and Activators of Transcription 3; NF $\kappa$ B: Nuclear factor $\kappa \mathrm{B} ; \mathrm{Nrf2}$ : Nuclear factor erythroid 2-related factor; ARE: Antioxidant Response Element. antioxidant enzymes in these cells. ${ }^{2)}$ While the expression level of $\mathrm{O}_{2}{ }^{-}$eliminating superoxide dismutase (SOD) isoenzymes (MnSOD and CuZnSOD) in $\beta$-cells is about $50 \%$ lower than in the liver, the expression levels of the $\mathrm{H}_{2} \mathrm{O}_{2}$-inactivating enzymes, catalase (CAT) and glutathione peroxidase ( $\mathrm{GPx})$ contribute to less than $2 \%$ of their levels of expression in the liver, ${ }^{3)}$ rendering $\beta$-cells particularly vulnerable to increased concentrations of $\mathrm{H}_{2} \mathrm{O}_{2}$.

The low antioxidant capacity provides pancreatic $\beta$-cells with an enhanced responsiveness to ROSmediated signaling. ${ }^{4)}$ As a small, uncharged, freely diffusible molecule, $\mathrm{H}_{2} \mathrm{O}_{2}$ is an efficient intracellular messenger that can be synthesized and degraded rapidly in response to external stimuli. ${ }^{5)}$ The $\mathrm{H}_{2} \mathrm{O}_{2}$ which is produced during glucose metabolism in $\beta$-cells serves as a metabolic signal for glucosestimulated insulin secretion (GSIS). ${ }^{4)}$ While low levels of ROS stimulate insulin release from $\beta$-cells, increased ROS levels reduce insulin expression and secretion, leading to $\beta$-cell damage. Therefore, maintenance of redox balance is critical for proper $\beta$-cell functioning. Slight stimulation of antioxidative enzyme expression exerts positive effects on $\beta$-cells by 
protecting them from oxidative stress, without hindering their ability to secrete insulin. ${ }^{6), 7)}$ In this regard, the stimulation of the endogenous antioxidant defenses in $\beta$-cells can be included in potential therapeutic approaches aimed at alleviating the harmful effects of oxidative stress on $\beta$-cells in diabetes. Any such consideration requires an understanding of the molecular events that underlie the regulation of antioxidant enzyme expression and activity.

Recent studies have stressed the important role of chemokine CXCL12 (C-X-C motif Ligand 12) in enhanced survival and regeneration of pancreatic $\beta$-cells. ${ }^{8)}$ CXCL12 binds to the CXC receptor 4 (CXCR4) and 7 (CXCR7), initiating signal transduction that elicits a variety of biological responses. ${ }^{9)}$ The main signaling pathways that are upregulated downstream of CXCL12 are phosphatidylinositol 3 kinase/Akt kinase (PI3K/Akt) and mitogen activated protein kinases (MAPK), such as extracellular signal regulated protein kinase (ERK) and p38 kinase. ${ }^{10), 11)}$ Activated PI3K/Akt kinases have a prosurvival role, primarily by inhibiting apoptotic pathways. ${ }^{12)}$ Activated ERK kinase also promotes cell survival, ${ }^{13)}$ while p38, depending on the type of activating stress, is involved in the inhibition of cell growth and induction of apoptosis, ${ }^{14)}$ but also promotes cell survival. ${ }^{15)}$

Positive effects of CXCL12 on $\beta$-cells were initially hinted by Yano et al. ${ }^{16)}$ who showed that $\beta$-cells overexpressing CXCL12 in RIP-SDF-1 transgenic mice are resistant to streptozotocin (STZ)induced $\beta$-cell apoptosis and diabetes. Furthermore, when islet $\beta$-cells are injured by different stimuli (STZ, cytokines, thapsigargin and glucotoxicity), they induce expression and secretion of CXCL12 that changes the biological function of adjacent $\alpha$ cells. The affected $\alpha$-cells cease producing glucagon and start to produce glucagon-like peptide-1 (GLP-1) which, in combination with CXCL12, promotes the growth, survival and viability of $\beta$-cells. ${ }^{17)}$ In our previous publications, we showed that the CXCL12overexpressing insulinoma $\beta$-cell line (Rin-5F) is more resistant to treatments with either $\mathrm{STZ}^{18}$ ) or $\mathrm{H}_{2} \mathrm{O}_{2}{ }^{19)}$ in comparison to wild-type (wt) Rin-5F cells. In addition, we showed that pretreatment of wt and primary rat islet cells with recombinant CXCL12 improved their viability and insulin gene expression after $\mathrm{H}_{2} \mathrm{O}_{2}$ treatment. Even though these results showed that CXCL12 overexpression redirects $\mathrm{H}_{2} \mathrm{O}_{2}$ induced cell death from the necrotic to the apoptotic pathway mediated by Akt kinase, ${ }^{19)}$ they strongly suggest that CXCL12 overexpressing $\beta$-cells, when compared with wt cells, were more resistant to oxidative stress mediated by $\mathrm{H}_{2} \mathrm{O}_{2}$, with their cellular functions remaining preserved.

To extend our previous studies, the aim of this work was to examine the mechanism of the proposed CXCL12-mediated increased resistance to $\mathrm{H}_{2} \mathrm{O}_{2}$ in $\beta$-cells. We analyzed the expression and activity of CAT, MnSOD and CuZnSOD enzymes in the CXCL12 overexpressing Rin-5F cell line and in rat islets exogenously supplemented with CXCL12, in the control and $\mathrm{H}_{2} \mathrm{O}_{2}$-induced state of oxidative stress. To assess the underlying mechanisms of antioxidative enzyme regulation by CXCL12, we analyzed the activities of the CXCL12-induced downstream kinases (Akt, ERK and p38) and their target transcription factors $(\mathrm{Sp} 1, \mathrm{C} / \mathrm{EBP} \beta, \mathrm{STAT} 3$, $\mathrm{NF} \kappa \mathrm{B}, \mathrm{Nrf2}$ ). We report for the first time that CXCL12, by activating Akt, ERK and p38 and inducing nuclear translocation and binding of Nrf2 to the CAT gene promoter, promotes CAT expression and activity, thus contributing to the functional resistance of $\beta$-cells to $\mathrm{H}_{2} \mathrm{O}_{2}$.

\section{Materials and methods}

Cell culture and treatment. We used the rat pancreatic islet tumor cell line Rin-5F (ATCC-CRL2058) wild-type (wt), the same cell line with a stable transfected human gene for CXCL12 (\#1) in which CXCL12 expression is 170-fold higher than endogenous CXCL12 expression in the rat ${ }^{18), 20)}$ and empty vector-transfected Rin-5F (mock) cells. Cells were cultured in RPMI medium supplemented with $10 \%$ FBS, $2 \mathrm{mM}$ L-glutamine, penicillin $(100 \mathrm{U} / \mathrm{mL})$ and streptomycin $(100 \mu \mathrm{g} / \mathrm{mL})$ in a humidified $(95 \%)$ atmosphere and $5 \% \mathrm{CO}_{2}$ at $37^{\circ} \mathrm{C}$. All cell culture reagents were obtained from PAA Laboratories $\mathrm{GmbH}$, Austria. The cells were treated with an $\mathrm{IC}_{50}$ dose of $\mathrm{H}_{2} \mathrm{O}_{2}$ for $1 \mathrm{~h}$ (unless otherwise indicated). Recovering cells were transferred in complete medium and incubated for an additional $2 \mathrm{~h}$ or $12 \mathrm{~h}$ after the $\mathrm{H}_{2} \mathrm{O}_{2}$ treatment. The $\mathrm{IC}_{50}$ concentrations of $\mathrm{H}_{2} \mathrm{O}_{2}$ were $75 \mu \mathrm{M}$ for wt and $150 \mu \mathrm{M}$ for $\# 1$ cells, as described. ${ }^{19)}$

Preparation of rat pancreatic islet cells. All animal procedures were in compliance with Directive $2010 / 63 / \mathrm{EU}$ on the protection of animals used for experimental and other scientific purposes, and were approved by the Ethical Committee for the Use of Laboratory Animals of the Institute for Biological Research "Siniša Stanković", University of Belgrade. Adult (2.5-month-old) male albino Wistar rats 
weighing 220-250g were kept under controlled environmental conditions $(12 \mathrm{~h}$ light/dark cycle, $22 \pm 2{ }^{\circ} \mathrm{C}, 50 \%$ relative humidity). Standard food pellets and tap water were provided ad libitum. The islets were isolated in Hank's balanced salt solution (HBSS): $115 \mathrm{mM} \mathrm{NaCl}, 10 \mathrm{mM} \mathrm{NaHCO}_{3}$, $5 \mathrm{mM} \mathrm{KCl}, 1.2 \mathrm{mM} \mathrm{NaH}_{2} \mathrm{PO}_{4}, 25 \mathrm{mM}$ HEPES, $1.1 \mathrm{mM} \mathrm{MgCl}{ }_{2}$, supplemented with $1 \%$ bovine serum albumin (BSA, fraction V, Sigma) and $5 \mathrm{mM}$ glucose, according to the slightly modified procedure previously described. ${ }^{19), 21)}$ Islet cells were pretreated with $80 \mathrm{ng} / \mathrm{ml}$ of recombinant murine CXCL12alpha (Sigma) for $30 \mathrm{~min}$ and/or treated for $1 \mathrm{~h}$ with $45 \mu \mathrm{M} \mathrm{H} \mathrm{O}_{2}\left(\mathrm{IC}_{50}\right) .{ }^{19)}$

Alkaline comet assay. To estimate and compare the levels of DNA damage in different experimental groups we used the Comet assay as already described. ${ }^{18)}$ DNA damage was quantified by measuring the displacement of the genetic material between the nucleus ('comet head') and the resulting 'comet tail'. Images were analyzed with TriTekCometScoree Freeware version 1.5 (http://www.AutoComet.com).

Lipid peroxidation assay. The level of lipid peroxidation was estimated by measuring the concentration of the reactive by-product malondialdehyde (MDA) in the thiobarbituric acid-reactive substance assay (TBARS) as described. ${ }^{22)}$ The concentration of MDA was expressed as nM MDA/ mg proteins. Protein concentrations were determined according to Lowry et al. ${ }^{23)}$

Superoxide dismutase and catalase activities. The cells were resuspended in sucrose buffer (0.25 M sucrose, $1 \mathrm{mM}$ EDTA and $0.05 \mathrm{M}$ Tris-HCl, $\mathrm{pH} 7.4$ ), sonicated for $30 \mathrm{~s}$ at $20 \mathrm{~Hz}$ on ice, and the obtained homogenates were centrifuged for $1 \mathrm{~min}$ at $14,000 \times \mathrm{g}$ at $4{ }^{\circ} \mathrm{C}$. Aliquots of the obtained supernatants were used for protein concentration determination and measurement of CAT and SOD activities. Total SOD activity was measured by the epinephrine method. ${ }^{24)}$ MnSOD activity was assessed after preincubation with $8 \mathrm{mM} \mathrm{KCN}$. CuZnSOD activity was the difference between total SOD and MnSOD activities. CAT activity was measured by the rate of $\mathrm{H}_{2} \mathrm{O}_{2}$ decomposition. ${ }^{25)}$ SOD and CAT activities were expressed as $\mathrm{U} / \mathrm{mg}$ proteins.

Immunoblot analysis. Cell cytosol, nuclear fractions and lysates were prepared using the ProteoJET Cytoplasmic and Nuclear Protein Extraction Kit and ProteoJET Mammalian Cell Lysis Reagent (Fermentas), respectively, according to the manufacturer's instructions. Proteins $(20 \mu \mathrm{g})$ separated by sodium dodecyl sulfate (SDS) polyacryl- amide gel electrophoresis (PAGE) were transferred onto polyvinylidene difluoride membranes, blocked for $1 \mathrm{~h}$ at room temperature with $5 \%$ non-fat dry milk in blotto base buffer $(0.1 \%$ Tween $20,20 \mathrm{mM}$ Tris- $\mathrm{HCl} \mathrm{pH} 7.6,137 \mathrm{mM} \mathrm{NaCl})$ and examined by immunoblot analysis using the following antibodies: anti-MnSOD, anti-CuZnSOD, anti-Akt $1 / 2 / 3$, antipAkt $1 / 2 / 3$, anti-ERK $1 / 2$, anti-pERK, anti-p38, anti-p-p38, anti-Nrf2, anti-NF $\kappa$ B-p65, anti-STAT3, anti-Sp1, anti-C/EBP $\beta$, anti-lamin B (Santa Cruz Biotechnology), anti-catalase and anti- $\beta$-actin (Abcam). Staining was performed by the chemiluminescent technique according to the manufacturer's instructions (Amersham Pharmacia Biotech). Quantification of immunoreactive bands was performed using TotalLab (Phoretix) electrophoresis software (ver. 1·10).

RNA isolation and real-time quantitative PCR analysis (RT-qPCR). Total RNA was prepared from Rin-5F (wt and \#1) and islet cells using the GeneJET RNA Purification Kit (Thermo Fisher Scientific). Cells were treated with $\mathrm{H}_{2} \mathrm{O}_{2}\left(\mathrm{IC}_{50}\right)$ for $1 \mathrm{~h}$ and allowed to recover in the medium either for 2 or $12 \mathrm{~h}$. For complementary DNA synthesis, total RNA $(1 \mu \mathrm{g})$ was treated with DNAse I and reverse transcribed with RevertAid First Strand cDNA Synthesis Kit (Fermentas) using oligo(dT) primers. mRNA levels were quantified by RT-qPCR using an ABI Prism 7000 Sequence Detection System (Applied Biosystems) and a Maxima SYBR Green/ ROX qPCR Master Mix (Fermentas). The fragments were amplified using the following primers (Invitrogen): forward 5'-CAGATCATGCAGCTGCACCA$3^{\prime}$ and reverse 5'-TCAGTCCAGGCTGAAGAGCA$3^{\prime}$ for the rat MnSOD gene; forward 5'-GCAGAAGGCAAGCGGTGAAC-3' and reverse $5^{\prime}$ CGGCCAATGATGGAATGCTC- $3^{\prime}$ for the rat CuZnSOD gene; forward 5'-GCGAATGGAGAGGCAGTGTAC-3' and reverse 5'-GAGTGACGTTGTCTTCATTAGCACTG-3' for the rat CAT gene; forward 5'-ATGGCCCTGTGGATGCGCTT-3' and reverse 5'-ACAATGCCACGCTTCTGCCG-3' for the rat insulin 1 gene (Ins1); forward $5^{\prime}$-AGATTACTGCCCTGGCTCCT- $3^{\prime}$ and reverse $5^{\prime}$ ACATCTGCTGGAAGGTGGAC-3' for the rat $\beta$ actin gene. The programme for RT-qPCR was as follows: initial denaturation step at $95{ }^{\circ} \mathrm{C}$ for $10 \mathrm{~min}$; two-step PCR program at $95^{\circ} \mathrm{C}$ for $15 \mathrm{~s}$ and at $60^{\circ} \mathrm{C}$ for $60 \mathrm{~s}, 40$ cycles. Negative controls without the template were used in all $\mathrm{RT}$-qPCR reactions. The expression levels of the target genes were related to the averaged expression level of rat $\beta$-actin as the 
housekeeping gene. RT-qPCR reactions were carried out in triplicate.

Chromatin immunoprecipitation (ChIP). Chromatin was prepared from Rin-5F cells subjected to a $2 \mathrm{~h}$ recovery period after treatment with an $\mathrm{IC}_{50}$ dose of $\mathrm{H}_{2} \mathrm{O}_{2}$. The ChIP assay was performed using the ChIP-IT Express kit (Active Motif) according to the manufacturer's. The cells were fixed with $1 \%$ formaldehyde for $10 \mathrm{~min}$ at room temperature prior to lysis and isolation of nuclei. Chromatin was sheared by sonication on ice with 10 pulses (each consisted of a $20 \mathrm{~s}$ sonication at $50 \mathrm{~Hz}$ followed by a $30 \mathrm{~s}$ rest on ice). The sheared chromatin yielded a smear between 200-1100 bp; this was used in an immunoprecipitation reaction performed with $3 \mu \mathrm{g}$ of anti-Nrf2 antibody (Santa Cruz) and $20 \mu \mathrm{g}$ of DNA for all of the analyzed chromatin samples, so that the initial amounts of DNA were equal for all ChIP reactions. After pelleting the immune complexes by Protein G magnetic beads, the bound DNA was eluted, and the cross-links were reversed by heating the samples in Reverse Cross-linking Buffer at $95^{\circ} \mathrm{C}$ for $15 \mathrm{~min}$, followed by incubation with $1 \mu \mathrm{g}$ of proteinase $\mathrm{K}$ for $1 \mathrm{~h}$ at $37^{\circ} \mathrm{C}$. To validate $\mathrm{ChIP}$ methodology, the same immunoprecipitation procedure was performed using antibodies for RNA Pol II (Active Motif) and IgG (Santa Cruz), which served as positive and negative controls, respectively. The DNA samples from the ChIP reaction and the "input" DNA corresponding to the DNA aliquots that were not submitted to immunoprecipitation were amplified in a Mastercycler pro (Eppendorf) using the optimized number of cycles during the linear phase of amplification for agarose gel electrophoresis. After an initial melt step at $95^{\circ} \mathrm{C}$ for $3 \mathrm{~min}, 33$ cycles of: $95^{\circ} \mathrm{C}$ for $20 \mathrm{~s}, 59^{\circ} \mathrm{C}$ for $30 \mathrm{~s}$ and $72^{\circ} \mathrm{C}$ for $30 \mathrm{~s}$, and a hold cycle at $10^{\circ} \mathrm{C}$ were performed. Quantification of ChIP analysis was performed using RT-qPCR in the ABI Prism 7000 Sequence Detection System (Applied Biosystems) according to the ChIP-IT Express kit (Active Motif) method. Average Ct values for Nrf2 samples and IgG controls were expressed as the percentage of the input (\% input). The primers were as follows: forward 5'-TACCACATCTTTGTCAAATC-3' and reverse 5'-AATATTTGGTGACTTTGTCG-3' for the ARE1 region (201 bp amplicons); forward 5'-GTCCACCTCCCGGAGCCCAC-3' and reverse 5'-CAGGCCCGCTGGAGTGGTGA-3' for the ARE2 region (149 bp amplicons).

Bioinformatic procedure. Nrf2 binding sites in the rat CAT gene promoter element $(-1418 /$ $+22 \mathrm{bp}$ ) were predicted by ALGGEN-PROMO software (www.alggen.Isi.upc.es) and Genomatix MatInspector software (www.genomatix.de). The analyzed rat CAT gene promoter element, characterized by Nakashima et al. ${ }^{26)}$ is available on: NCBI/ GenBank:AH004967.1/Rat Catalase gene/exon1; Rattus norvegicus, Location: Chromosome 3 (3q32q34).

Statistical analysis. The results are presented as means \pm SEM of three independent experiments (run in duplicate). Statistical significance was evaluated by Student's t test or one-way ANOVA for multiple comparisons; the statistical significance level was at $\mathrm{p}<0.05$.

\section{Results}

CXCL12 overexpression reduces $\mathrm{H}_{2} \mathrm{O}_{2}$-mediated oxidative stress in the $\boldsymbol{\beta}$-cell line. To assess the degree of oxidative stress induced by $\mathrm{H}_{2} \mathrm{O}_{2}$ in Rin$5 \mathrm{~F}$ wt, mock and CXCL12 overexpressing cells (\#1), we analyzed the levels of lipid peroxidation and DNA damage (Fig. 1). Examination of MDA concentrations revealed that the $\mathrm{H}_{2} \mathrm{O}_{2}$ treatment led to an increase in lipid peroxidation in wt and mock (2.4fold and 2.3-fold respectively), and in \#1 (1.6-fold) cells compared to matching controls (Fig. 1A). To assess cell recovery from the oxidative stress, the cells were incubated for $12 \mathrm{~h}$ in complete medium. This step was performed to obtain an estimate of their ability to survive and repair the damage caused by the exposure to $\mathrm{H}_{2} \mathrm{O}_{2}$. The recovery period was accompanied by further induction of lipid peroxidation in wt and mock cells, which was 2.7-fold and 2.6fold, respectively, higher than in matching controls. In contrast, the concentration of MDA in $\# 1$ was at the control level after recovery. The results of the Comet assay (Fig. 1B) show that the comet tail moment, a measure of DNA damage, was extremely low and similar in all cell lines under control conditions. After a $1 \mathrm{~h} \mathrm{H}_{2} \mathrm{O}_{2}$ treatment, the tail moment was 13.5-, 14.4- and 8.7 fold higher in wt, mock and \#1 cells, respectively, as compared to matching controls. After the $12 \mathrm{~h}$ recovery period, the tail moment remained increased and in wt and mock cells it was 8-fold higher, whereas in \#1 cells it was 3 -fold higher, as compared to matching controls. The significantly lower level of DNA-damage and lipid peroxidation in $\# 1$ cells compared to wt and mock cells suggests that CXCL12 overexpressing \#1 cells possess a higher level of endogenous antioxidant protection than wt cells. This could explain the increased survival of $\# 1$ cells after the $\mathrm{H}_{2} \mathrm{O}_{2}$ treatment reported previously. ${ }^{19)}$ 
A

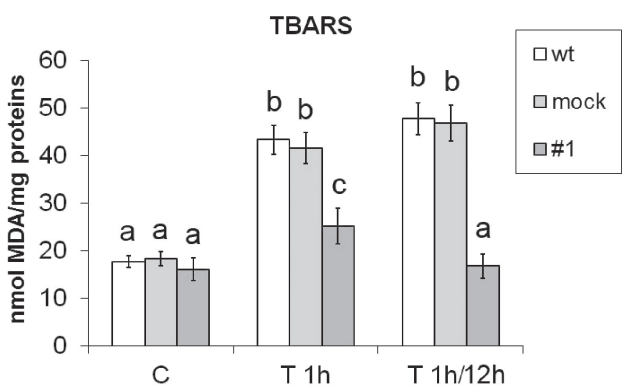

B
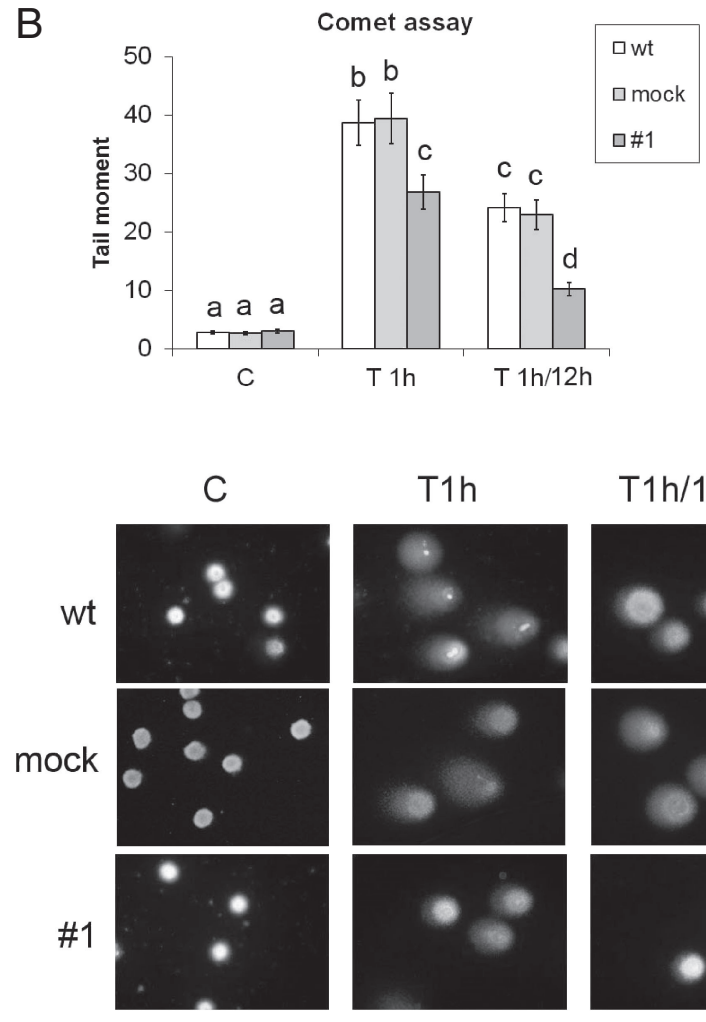

$\mathrm{T} 1 \mathrm{~h}$

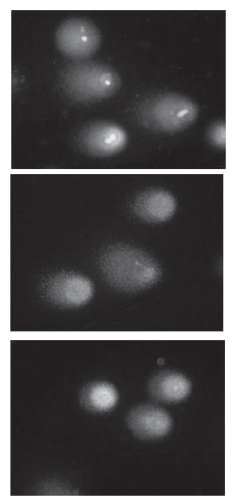

$\mathrm{T} 1 \mathrm{~h} / 12 \mathrm{~h}$

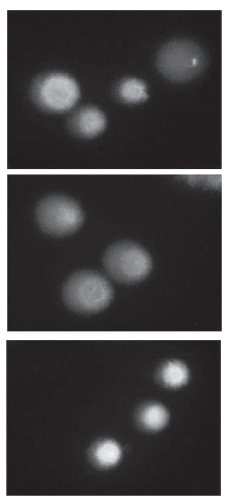

Fig. 1. Overexpression of CXCL12 attenuates oxidative stress in Rin-5F cells after $\mathrm{H}_{2} \mathrm{O}_{2}$ treatment. (A) The level of lipid peroxidation, determined by the TBARS assay. (B) DNA integrity was determined by the Comet assay according to which the tail moment serves as the measure of DNA damage. Representative images of cell comets are presented. wt - wildtype Rin-5F; empty vector-transfected Rin-5F - mock; \#1 CXCL12 overexpressing Rin-5F; C - control; T1h $-\mathrm{H}_{2} \mathrm{O}_{2}$ treatment for $\left(\mathrm{IC}_{50} ; 1 \mathrm{~h}\right) ; \mathrm{T} 1 \mathrm{~h} / 12 \mathrm{~h}$ - treatment with $\mathrm{H}_{2} \mathrm{O}_{2}$ $\left(\mathrm{IC}_{50}\right)$ for $1 \mathrm{~h}$ followed by a $12 \mathrm{~h}$ recovery in standard medium. $\mathrm{IC}_{50}$ concentrations of $\mathrm{H}_{2} \mathrm{O}_{2}$ are explained in the Materials and Methods. Results are expressed as means \pm SEM. Means not sharing a common letter are significantly different between groups $(\mathrm{p}<0.05)$.

Effects of CXCL12 on $\beta$-cell line and islet cell antioxidant enzyme activities and protein levels. To assess the antioxidant protection status of
CXCL12 overexpressing \#1 cells as compared to wt and mock cells, we measured the activities and protein levels of MnSOD, CuZnSOD and CAT (Fig. 2). Analysis of the activity and expression of antioxidant enzymes at $1 \mathrm{~h}$ after $\mathrm{H}_{2} \mathrm{O}_{2}$ treatment allowed us to compare the abilities of the cells to immediately respond to the $\mathrm{H}_{2} \mathrm{O}_{2}$ attack, whereas the $12 \mathrm{~h}$ recovery period served to monitor and compare the different $\mathrm{H}_{2} \mathrm{O}_{2}$-induced molecular signals and their effects on the activities and expression of antioxidant enzymes in the remaining viable cells. Given that no differences between wt and mock cells were recorded (Fig. 2A,B), the activities and protein levels of antioxidant enzymes in CXCL12 overexpressing \#1 cells were expressed in relation to wt cells. Under control conditions, the activity of MnSOD was at the same level in wt and \#1 cells. The $1 \mathrm{~h} \mathrm{H}_{2} \mathrm{O}_{2}$ treatment induced MnSOD activity only in wt cells by $15 \%$ (Fig. $2 \mathrm{~A}$ ). In cells that were allowed to recover for $12 \mathrm{~h}$ after the $\mathrm{H}_{2} \mathrm{O}_{2}$ treatment, MnSOD activity was induced in both cell lines, and was $33 \%$ higher in wt cells than in \#1 cells. Likewise, the activity of CuZnSOD was at a similar level in both cell lines under control conditions. The $\mathrm{H}_{2} \mathrm{O}_{2}$ treatment significantly affected CuZnSOD activity in both cell lines, increasing it by $12 \%$ in wt cells and reducing it for $17 \%$ in $\# 1$ cells relative to matching controls. As observed for MnSOD, cell recovery was accompanied by an increase in CuZnSOD activity in both cell lines so that CuZnSOD activity was $23 \%$ higher in wt than in $\# 1$ cells. Under control conditions, CAT activity was increased by $125 \%$ in \#1 cells as compared to wt cells. $\mathrm{H}_{2} \mathrm{O}_{2}$-treatment caused a slight decrease in CAT activity in both cell lines, with CAT activity being higher in \#1 cells by $153 \%$ as compared to wt cells. After recovery from the $\mathrm{H}_{2} \mathrm{O}_{2}$ treatment, CAT activity remained slightly elevated in both cell lines as compared to matching control cells; it was higher by $116 \%$ in \#1 cells than in wt cells. These results indicate that the differences in CAT activity between wt and $\# 1$ cell lines were more pronounced than the differences between the activities of SOD entities. CAT activity was more than 2-fold higher in \#1 cells than in wt cells under the analyzed conditions, suggesting that CAT provided increased protection in CXCL12 overexpressing \#1 cells.

We next assessed CAT activity in primary cells isolated from rat pancreatic islets. Prior to exposure to $\mathrm{H}_{2} \mathrm{O}_{2}(45 \mu \mathrm{M} / 1 \mathrm{~h})$, the cells were incubated with recombinant CXCL12 protein $(80 \mathrm{ng} / \mathrm{ml})$ for $30 \mathrm{~min}$. This was followed by cell recovery in complete 
A
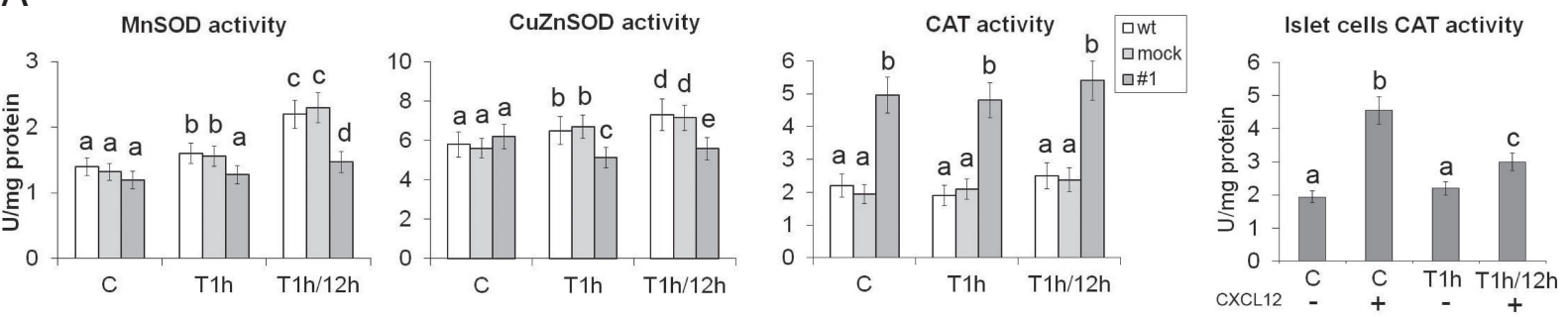

B
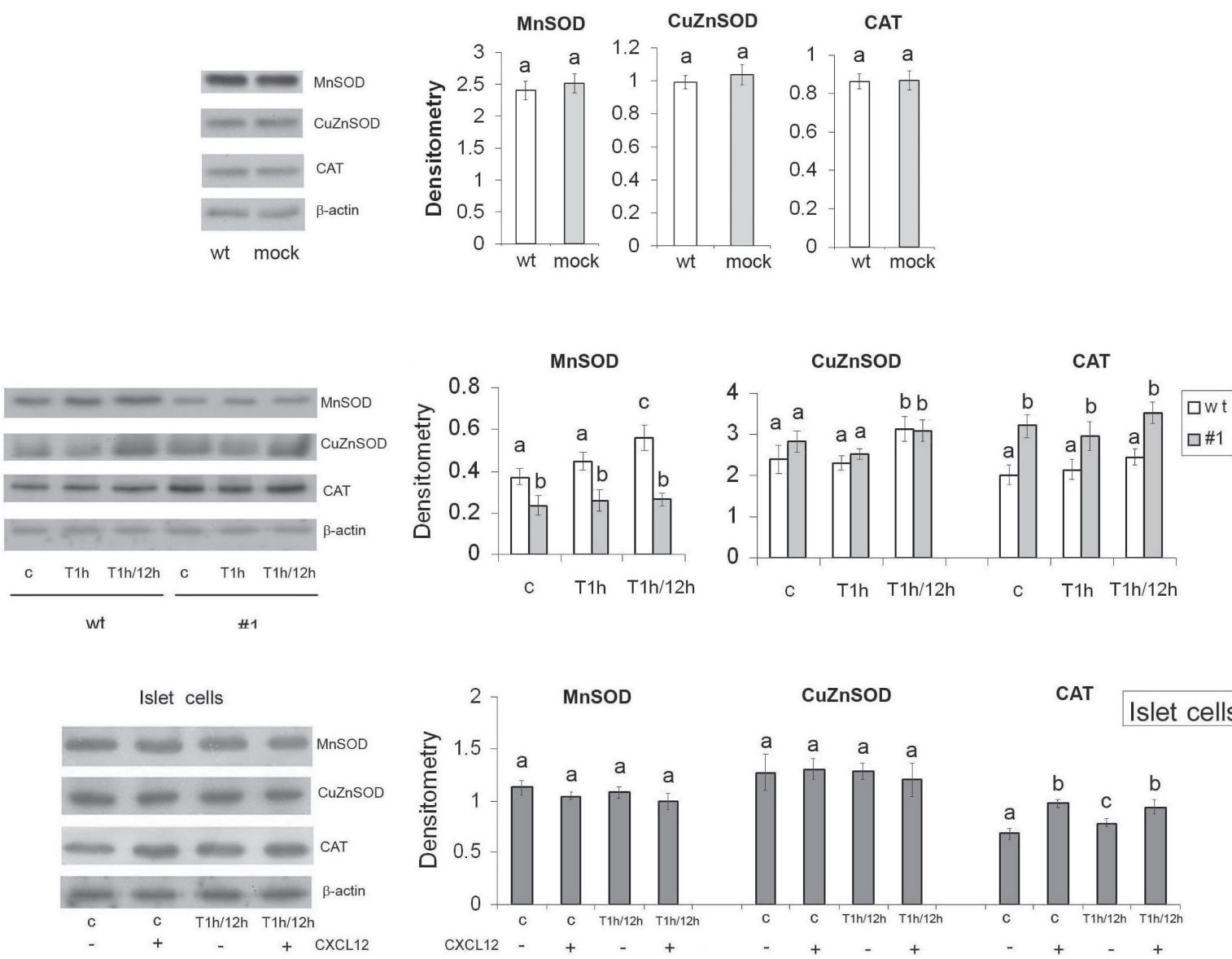

Fig. 2. CXCL12 overexpression modifies the endogenous antioxidant enzymes' activities and protein levels in Rin-5F and islet cells in basal and oxidative stress conditions. (A) CuZnSOD, MnSOD and CAT enzyme activities in pancreatic cells. (B) Relative protein levels of CuZnSOD, MnSOD and CAT in pancreatic cells estimated by immunoblot analysis of homogenates. Representative blots from three independent experiments are shown. The results of quantification of the immunoreactive bands relative to $\beta$-actin loading controls are presented in the graphs. wt - wild-type Rin-5F; empty vector-transfected Rin-5F - mock; \#1 - CXCL12 overexpressing Rin-5F; (+) and $(-)$ - islet cells with or without pretreatment with recombinant CXCL12 $(80 \mathrm{ng} / \mathrm{ml} ; 30 \mathrm{~min})$. C - control; T1h $\mathrm{H}_{2} \mathrm{O}_{2}\left(\mathrm{IC}_{50}\right)$ treated for $1 \mathrm{~h}$. T1h/12h $-\mathrm{H}_{2} \mathrm{O}_{2}\left(\mathrm{IC}_{50}\right)$ treatment for $1 \mathrm{~h}$ followed by $12 \mathrm{~h}$ recovery. Results are expressed as means \pm SEM. Means not sharing a common letter are significantly different between groups $(\mathrm{p}<0.05)$. 
medium for $12 \mathrm{~h}$ (Fig. 2A). The pretreatment with CXCL12 increased CAT activity by $134 \%$ in control cells and by $30 \%$ in $\mathrm{H}_{2} \mathrm{O}_{2}$-treated cells. Under control conditions, the CXCL12-mediated elevation of CAT activity in islet cells was similar to that recorded in CXCL12 overexpressing \#1 cells (about 2-fold). While CXCL12-stimulated CAT activity by about $30 \%$ in $\mathrm{H}_{2} \mathrm{O}_{2}$-treated islet cells was not increased to the same extent as in Rin- $5 \mathrm{~F}$ cells, in which it was increased by $116 \%$, this increase was significant. Together, these results suggest that stimulation of CAT activity is a CXCL12-mediated mechanism that enhances $\beta$-cell viability and functionality in $\mathrm{H}_{2} \mathrm{O}_{2}$ induced oxidative stress.

Western blot analysis of cell homogenates showed that the level of MnSOD protein was higher in wt than in $\# 1$ cells under all analyzed conditions, and even more so after the $12 \mathrm{~h}$ recovery (Fig. 2B). The MnSOD protein level was higher by $37 \%$ in the control, whereas after $12 \mathrm{~h}$ of cell recovery it was increased by $53 \%$ in wt cells compared to $\# 1$ cells. The relative amounts of CuZnSOD proteins were similar between wt and $\# 1$ cells under analyzed conditions. After the $12 \mathrm{~h}$ recovery period, the level of CuZnSOD protein increased in both cell lines when compared to matching controls. The level of CAT protein was consistently significantly higher in \#1 cells than in wt cells in all of the above experimental groups, despite the slight decrease in CAT protein in $\# 1$ cells after the $\mathrm{H}_{2} \mathrm{O}_{2}$ treatment. In control conditions, the level of CAT protein was $60 \%$ higher in \#1 than in wt cells, whereas after recovery from the $\mathrm{H}_{2} \mathrm{O}_{2}$ treatment it was $44 \%$ higher. When primary islet cells were pretreated with CXCL12 $(80 \mathrm{ng} / \mathrm{ml} ; 30 \mathrm{~min})$ the level of CAT protein was significantly increased by $42 \%$. After the CXCL12pretreatment of islet cells before the $\mathrm{H}_{2} \mathrm{O}_{2}$ treatment $(45 \mu \mathrm{M} / 1 \mathrm{~h})$, followed by incubation in complete medium for $12 \mathrm{~h}$, the level of CAT protein was increased for $19 \%$ when compared to CXCL12 nonpretreated cells. MnSOD was slightly higher in nonpretreated islet cells but unlike in Rin-5F cells, this increase was not significant. The relative amount of CuZnSOD protein was similar under all analyzed conditions (Fig. 2B).

The effect of CXCL12 on antioxidant enzyme gene expression in $\boldsymbol{\beta}$-cells. RT-qPCR was used to examine the effect of CXCL12 overexpression on the levels of antioxidative enzyme gene expression (Fig. 3). Since transfection of Rin-5f cells with empty-vector (mock cells) had no effect on the cell's resistance to $\mathrm{H}_{2} \mathrm{O}_{2}$ (as judged by the TBARS and
Comet assays), and neither on CAT and $\mathrm{Mn} / \mathrm{Cu}$ / ZnSOD activities or protein levels, further analyses were performed using wt and $\# 1$ cells. mRNA was isolated from control, $\mathrm{H}_{2} \mathrm{O}_{2}$-treated $(1 \mathrm{~h})$ and cells whose potential for recovery after the $\mathrm{H}_{2} \mathrm{O}_{2}$ treatment was monitored after $12 \mathrm{~h}$. The level of MnSOD mRNA was 3 -fold higher in wt cells than in \#1 cells under control conditions. This difference was more pronounced after the $\mathrm{H}_{2} \mathrm{O}_{2}$ treatment, which induced MnSOD gene expression by $41 \%$ in wt cells and by $26 \%$ in $\# 1$ cells relative to matching controls. Although the level of MnSOD mRNA decreased in wt cells after the $12 \mathrm{~h}$ recovery period, it remained 3 -fold higher than in $\# 1$ cells. The levels of CuZnSOD mRNA in wt and \#1 cells were very similar under control conditions. After the $\mathrm{H}_{2} \mathrm{O}_{2}$ treatment, CuZnSOD mRNA increased in wt cells by $43 \%$ and in $\# 1$ by $30 \%$ in comparison with matching controls. After the $12 \mathrm{~h}$ recovery period, CuZnSOD mRNA returned to the control level in both cell lines. In contrast, under control conditions, the CAT mRNA level was higher by $69 \%$ in $\# 1$ cells as compared to wt cells. After the $\mathrm{H}_{2} \mathrm{O}_{2}$ treatment, CAT mRNA was significantly induced in both cell lines: in wt cells by $32 \%$ and in $\# 1$ cells by $20 \%$. After the post-treatment recovery period, further increases in CAT mRNA (by $59 \%$ in wt cells and $42 \%$ in \#1 cells) were observed. While CAT mRNA was significantly induced in both cell lines (both after the treatment and the post-treatment recovery period), the level of CAT mRNA was about $50 \%$ higher in \#1 than in wt cells.

To estimate the effect of CXCL12 on SOD and CAT mRNA levels in islet cells, mRNA was prepared from control and islet cells that were pretreated with CXCL12 (80 ng/ml; $30 \mathrm{~min})$, exposed to $\mathrm{H}_{2} \mathrm{O}_{2}$ $(45 \mathrm{\mu M} / 1 \mathrm{~h})$ and allowed to recover for $12 \mathrm{~h}$ (Fig. 3 ). Exogenous CXCL12 induced a nearly 2-fold increase in CAT mRNA in both control and $\mathrm{H}_{2} \mathrm{O}_{2}$-treated islet cells and suppressed MnSOD gene induction by $\mathrm{H}_{2} \mathrm{O}_{2}$. Application of CXCL12 caused a slight increase in CuZnSOD mRNA that was not statistically significant.

Insulin gene expression served as a measure of the functional viability of islet cells. Rat pancreas expresses two insulin genes (Ins1 and Ins2) which are regulated coordinately in normal rat pancreas, but are differentially regulated in response to different stimuli that cause changes in the level of total rat insulin mRNA. ${ }^{27)}$ Considering that selective expression of the Ins1 gene is a general feature of all Rin cell lines despite the presence of both normal insulin 

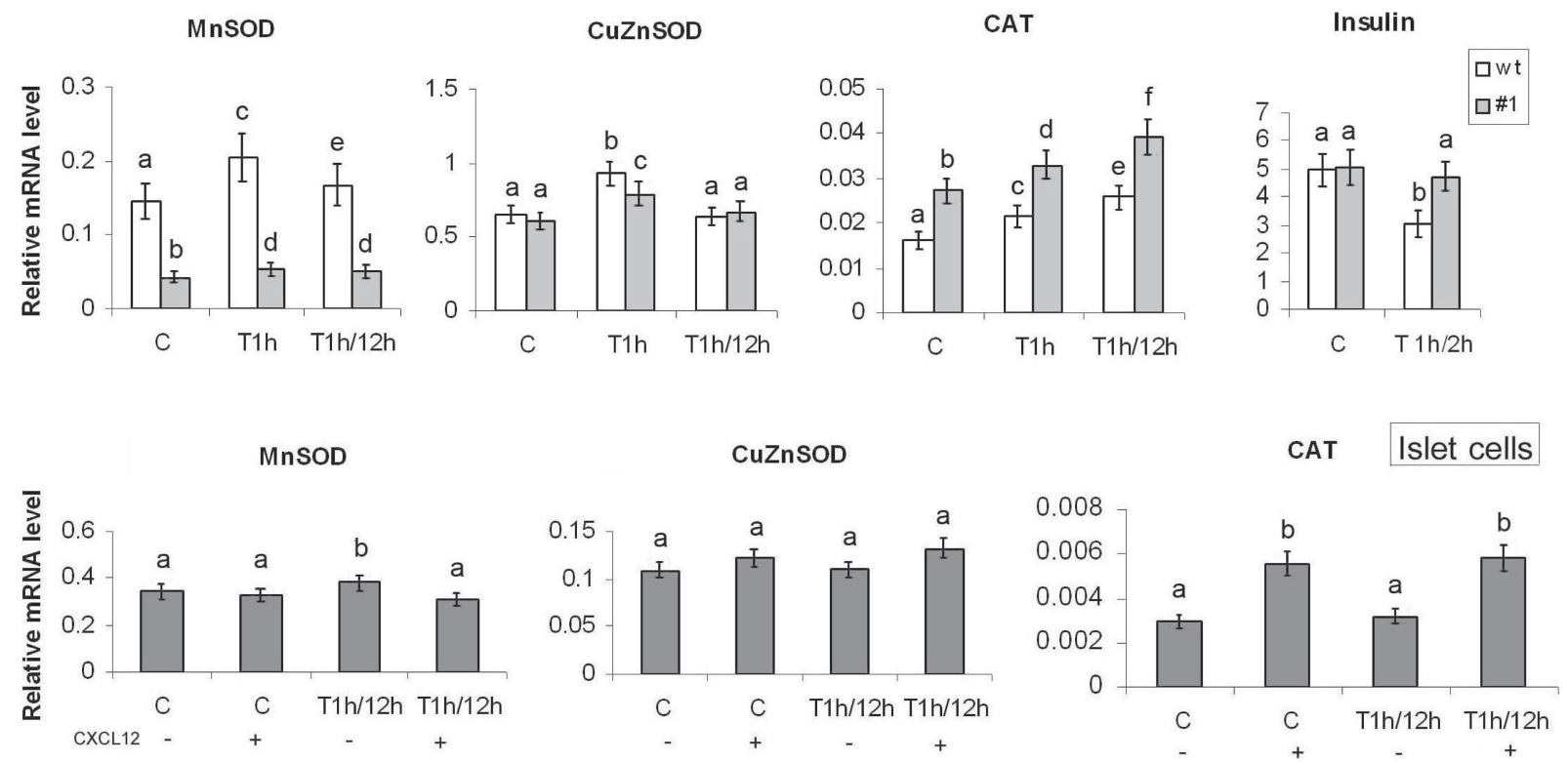

Fig. 3. CXCL12-mediated changes in antioxidant enzyme gene expression in Rin-5F and islet cells in basal and oxidative stress conditions. Insulin, CuZnSOD, MnSOD and CAT mRNA levels in pancreatic cells were determined by RT-qPCR; graphs show changes in mRNA levels relative to $\beta$-actin. wt - wild-type Rin-5F; $\# 1$ - CXCL12 overexpressing Rin-5F; (+) and $(-)$ - islet cells with or without pretreatment with recombinant CXCL12 $(80 \mathrm{ng} / \mathrm{ml} ; 30 \mathrm{~min})$. C - control; $\mathrm{T} 1 \mathrm{~h}-\mathrm{H}_{2} \mathrm{O}_{2}\left(\mathrm{IC}_{50}\right)$ treated for $1 \mathrm{~h} ; \mathrm{T} 1 \mathrm{~h} / 2 \mathrm{~h}-\mathrm{H}_{2} \mathrm{O}_{2}$ $\left(\mathrm{IC}_{50}\right)$ treated for $1 \mathrm{~h}$, followed by $2 \mathrm{~h}$ recovery in standard medium. $\mathrm{T} 1 \mathrm{~h} / 12 \mathrm{~h}-\mathrm{H}_{2} \mathrm{O}_{2}\left(\mathrm{IC}_{50}\right)$ treatment for $1 \mathrm{~h}$ followed by $12 \mathrm{~h}$ recovery. Results are expressed as means \pm SEM. Means not sharing a common letter are significantly different between groups $(\mathrm{p}<0.05)$.

genes (Ins1 and Ins2), ${ }^{28)}$ next we analyzed Ins1 expression. Examination of the effect of CXCL12 on Ins1 gene expression revealed stable levels of Ins1 mRNA in wt and \#1 cells under control conditions (Fig. 3). After the $2 \mathrm{~h}$ recovery period, a $39 \%$ decrease in Ins1 mRNA was observed in wt cells, whereas in \#1 cells it remained at the control level, indicating that CXCL12 overexpression did not disrupt but supported Ins1 gene expression in Rin$5 \mathrm{~F}$ cells after the $\mathrm{H}_{2} \mathrm{O}_{2}$ treatment. Together, these results suggest that CXCL12 protected $\beta$-cells from $\mathrm{H}_{2} \mathrm{O}_{2}$-induced stress through CAT induction. This is in agreement with the fundamental role CAT plays in $\mathrm{H}_{2} \mathrm{O}_{2}$ removal.

The effect of CXCL12 on factors potentially involved in the transcriptional regulation of CAT in $\boldsymbol{\beta}$-cells. Considering that the differences in CAT gene expression that were observed in $\beta$-cell lines and primary islet cells after the pretreatment step with CXCL12 as compared to untreated cells could be linked to CXCL12 overexpression, we analyzed the main signaling pathways downstream from the chemokine receptor.

Effect of CXCL12 on kinase phosphorylation. CXCL12 achieves its effects by activating the downstream kinases ERK, Akt and p38. In cells in which oxidative stress was induced by exposure to $\mathrm{H}_{2} \mathrm{O}_{2}$ we examined the levels of the phosphorylated forms of these kinases which reveal their activation. Maximal kinase phosphorylation/activation was reported to be attained within $60 \mathrm{~min}$ after the $\mathrm{H}_{2} \mathrm{O}_{2}$ treatment. ${ }^{29)}$ In subsequent experiments, cells were exposed to $\mathrm{H}_{2} \mathrm{O}_{2}$ for $5,15,30$ and $60 \mathrm{~min}$, and whole cells lysates were analyzed by Western blotting (Fig. 4A). The relative level of phosphorylated p38 (p-p38) was higher in $\# 1$ than in wt cells under control conditions, as well as after the $\mathrm{H}_{2} \mathrm{O}_{2}$ treatment at all-time points. In wt cells, maximal p-p38 level was observed 15 min after initiation of the $\mathrm{H}_{2} \mathrm{O}_{2}$ treatment, while in $\# 1$ cells p-p38 was slightly decreased $60 \mathrm{~min}$ after the $\mathrm{H}_{2} \mathrm{O}_{2}$ treatment. The highest level of p-ERK1/2 was detected in the \#1 cell line under control conditions, and was significantly higher than in control wt cells. The $\mathrm{H}_{2} \mathrm{O}_{2}$ treatment was accompanied by an increase in p-ERK1/2 in wt cells after 30 and $60 \mathrm{~min}$, while in $\# 1$ cells the level of p-ERK1/2 was reduced at all analyzed time points, while remaining higher in \#1 as compared to wt cells. Phosphorylation of Akt was consistently higher in \#1 cells than in wt cells at all time points. In wt cells, the maximal level of p-Akt was observed 15 min after initiation of the $\mathrm{H}_{2} \mathrm{O}_{2}$ treatment. To assess the effect 
A
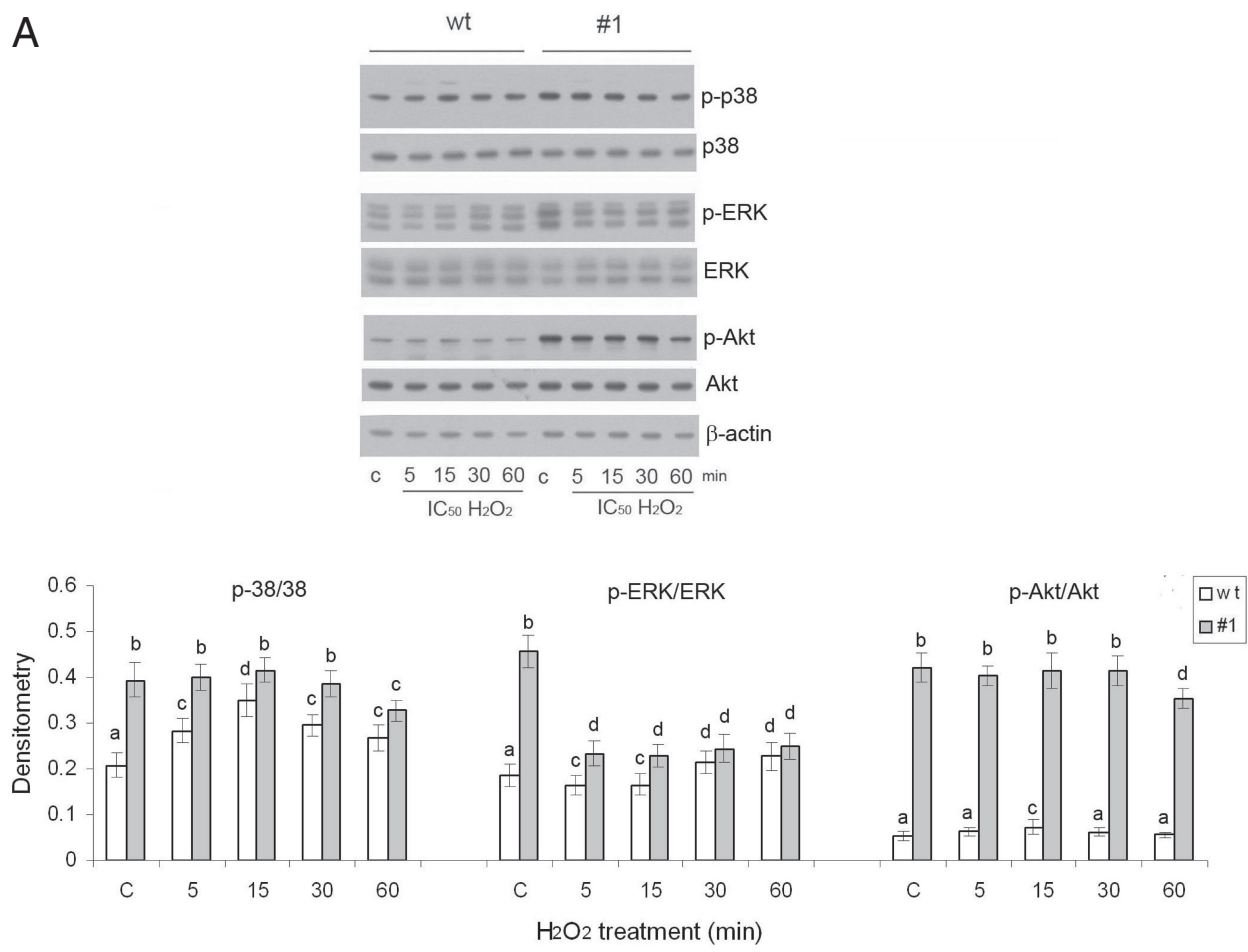

B
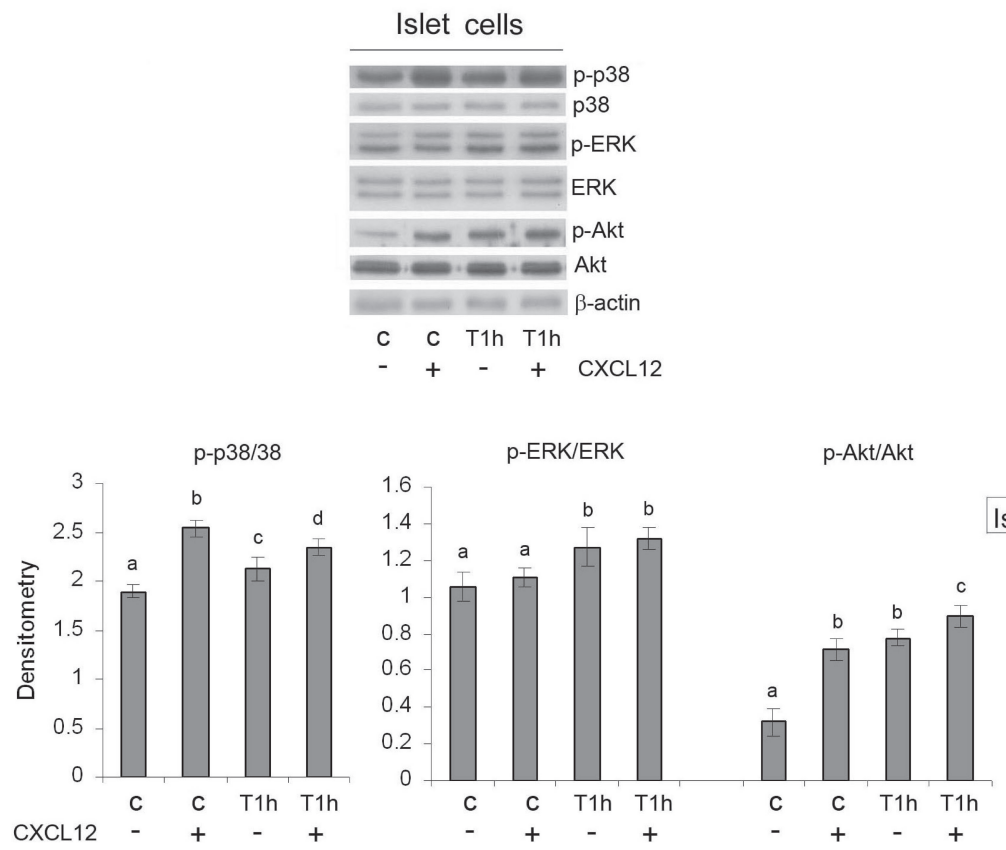

Fig. 4. Enhanced expression of CXCL12 activates downstream p38, ERK and Akt kinases in Rin-5F and islet cells in the basal state and after $\mathrm{H}_{2} \mathrm{O}_{2}$ treatment. Relative protein levels of p38, ERK and Akt and their phosphorylated forms (designated as p-p38, p-ERK and p-Akt, respectively) were determined by immunoblot analysis of cell lysates isolated from (A) Rin-5F and (B) islet cells. wt - wildtype Rin-5F; \#1 - CXCL12 overexpressing Rin-5F; (+) and (-) - islet cells with or without pretreatment with recombinant CXCL12 $(80 \mathrm{ng} / \mathrm{ml} ; 30 \mathrm{~min}) ; \mathrm{C}-$ control; 5, 15, 30, $60-\mathrm{H}_{2} \mathrm{O}_{2}\left(\mathrm{IC}_{50}\right)$-treated Rin-5F cells for 5, 15,30 and $60 \mathrm{~min} ; \mathrm{T} 1 \mathrm{~h}-\mathrm{H}_{2} \mathrm{O}_{2}\left(\mathrm{IC}_{50}\right)$ treatment for $1 \mathrm{~h}$. Representative blots from three independent experiments are shown. The results of quantification of the immunoreactive bands are presented in the graph depicting changes in p-kinase protein levels relative to matching kinase and $\beta$-actin loading controls. Results are expressed as means \pm SEM. Means not sharing a common letter are significantly different between groups $(\mathrm{p}<0.05)$. 
of CXCL12 on kinase activation in islet cells, the relative levels of the phosphorylated forms of the examined kinases were monitored in the control and $\mathrm{H}_{2} \mathrm{O}_{2}$-induced state of oxidative stress in islet cells pretreated with CXCL12 (80 ng/ml for $30 \mathrm{~min}$ ) (Fig. 4B). A 30 min pretreatment with CXCL12 was applied because maximal kinase activation by phosphorylation is induced by CXCL12 after exposure that lasts 1-120 min. ${ }^{10)}$ Under control conditions, the pretreatment with CXCL12 was accompanied by significantly increased p-p38 and p-Akt levels and a slight increase in p-ERK. After the $\mathrm{H}_{2} \mathrm{O}_{2}$ treatment $(45 \mu \mathrm{M} / 1 \mathrm{~h})$, the levels of p-p38 and p-Akt were higher in cells pretreated with CXCL12. The level of p-ERK was uniformly increased by the $\mathrm{H}_{2} \mathrm{O}_{2}$ treatment in CXCL12 non-pretreated and pretreated cells.

These results suggest that CXCL12 induces phosphorylation of p38, ERK and Akt kinases in the basal state. Activated kinases could mediate the activation of downstream transcription factors that are involved in the induction of CAT gene expression.

Effect of CXCL12 on the activities of transcription factors. To further elucidate the principal molecular mechanisms that are responsible for induced CAT gene expression, we characterized the molecular factors that operate at the transcriptional level and are known to be involved in the regulation of CAT, MnSOD and CuZnSOD gene transcription. We analyzed the presence and cellular localization of STAT3, NF $\kappa$ B-p65, Sp1, C/EBP $\beta$ and Nrf2 transcription factors (Fig. 5). To obtain insight into transcription factor activation and subsequent translocation from the cytoplasm to the nucleus after the activation of different molecular signals by $\mathrm{H}_{2} \mathrm{O}_{2}$, cell fractions were isolated from wt and $\# 1$ cells that were maintained under the following conditions: control (basal), from cells $1 \mathrm{~h}$ after initiation of the $\mathrm{H}_{2} \mathrm{O}_{2}$ treatment, and from cells that were allowed to recover from the $\mathrm{H}_{2} \mathrm{O}_{2}$ treatment for $2 \mathrm{~h}$ in complete medium. Based on the nuclear translocation, we concluded that STAT3 and NF $\kappa$ B-p65 were more active in wt than in $\# 1$ cells under both control and oxidative stress conditions (Fig. $5 \mathrm{~A}$ ). NF $\kappa \mathrm{B}$-p65 was significantly induced in wt cells immediately after the $1 \mathrm{~h}$ treatment with $\mathrm{H}_{2} \mathrm{O}_{2}$ and remained increased after the $2 \mathrm{~h}$ recovery period. In contrast, in $\# 1$ cells only a faint induction of NF $\kappa \mathrm{B}-\mathrm{p} 65$ was observed after recovery. In wt cells, the slight increase in nuclear translocation of STAT3 after the $\mathrm{H}_{2} \mathrm{O}_{2}$ treatment was maximal after the recovery period. In \#1 cells, the level of STAT3 in the nuclear fraction was reduced after the $2 \mathrm{~h}$ recovery period.
Sp1 displayed a higher increase in nuclear translocation in \#1 than in wt cells under control conditions; this relative increase was more pronounced at $1 \mathrm{~h}$ after the $\mathrm{H}_{2} \mathrm{O}_{2}$ treatment. Nuclear translocation of Sp1 was uniform in wt cells under all examined conditions. $\mathrm{C} / \mathrm{EBP} \beta$ was detected only in the nuclear fraction. In the control state, the nuclear level of $\mathrm{C} / \mathrm{EBP} \beta$ was higher in $\# 1$ cells than in wt cells. The $\mathrm{H}_{2} \mathrm{O}_{2}$ treatment induced an increase in the level of $\mathrm{C} / \mathrm{EBP} \beta$ in nuclei of both cell types, although it was higher in $\# 1$ cells than in wt cells. The recovery period was characterized by a decrease in $\mathrm{C} / \mathrm{EBP} \beta$ in wt cells, and its maximal induction in \#1 cells. Nuclear translocation of Nrf2 was significantly and persistently higher in \#1 cells than in wt cells in the control state and oxidative stress conditions (about 2-fold). In wt cells, Nrf2 nuclear translocation did not change under different conditions. In \#1 cells, maximal Nrf2 activation was detected after the $2 \mathrm{~h}$ recovery period (after the $\mathrm{H}_{2} \mathrm{O}_{2}$ treatment).

The obtained data strongly suggest roles for Sp1, $\mathrm{C} / \operatorname{EBP} \beta$ and Nrf2 in the upregulation of CAT gene transcription in CXCL12 overexpressing cells. Given that $\mathrm{C} / \operatorname{EBP} \beta$ and $\mathrm{Sp} 1$ are established regulators of CAT gene expression, whereas the activity of Nrf2 on the CAT gene promoter is insufficiently explored, the role of Nrf2 in CAT gene regulation was examined further. Nuclear translocation of Nrf2 was induced in islets cells pretreated with CXCL12 $(80 \mathrm{ng} / \mathrm{ml}$ for $30 \mathrm{~min})$ that were maintained under control conditions (for 96\%), or after the $\mathrm{H}_{2} \mathrm{O}_{2}$ treatment $(45 \mu \mathrm{M} / 1 \mathrm{~h})$ and the $2 \mathrm{~h}$ recovery period (for 64\%) (Fig. 5B). This result further supports the hypothesis that the CXCL12-stimulated nuclear translocation of Nrf2 was responsible for the induction of CAT expression which was examined next.

CXCL12 overexpression enhances Nrf2 binding affinity towards the CAT gene promoter in pancreatic $\boldsymbol{\beta}$-cell lines. Analysis of the CAT gene promoter revealed the presence of several potential Nrf2 binding sites (Fig. 6A). One site was identified as a putative Nrf2 binding site (-998/ $-988 \mathrm{bp}$ ) that contains a potential Nrf2/MafK binding site $(-996 /-990 \mathrm{bp})$. Three additional sites (at positions: -199/-193 bp; -168/-162 bp; -135/ $-129 \mathrm{bp}$ ) were identified as putative Nrf2/MafK binding sites. The binding of Nrf2 to the CAT gene promoter was examined by ChIP analysis with antiNrf2 antibody (Fig. 6B). Chromatin was prepared from control and cells that were allowed to recover for $2 \mathrm{~h}$ after the $\mathrm{H}_{2} \mathrm{O}_{2}$ treatment. The anti-Nrf2 antibody precipitated the part of the CAT promoter 
A
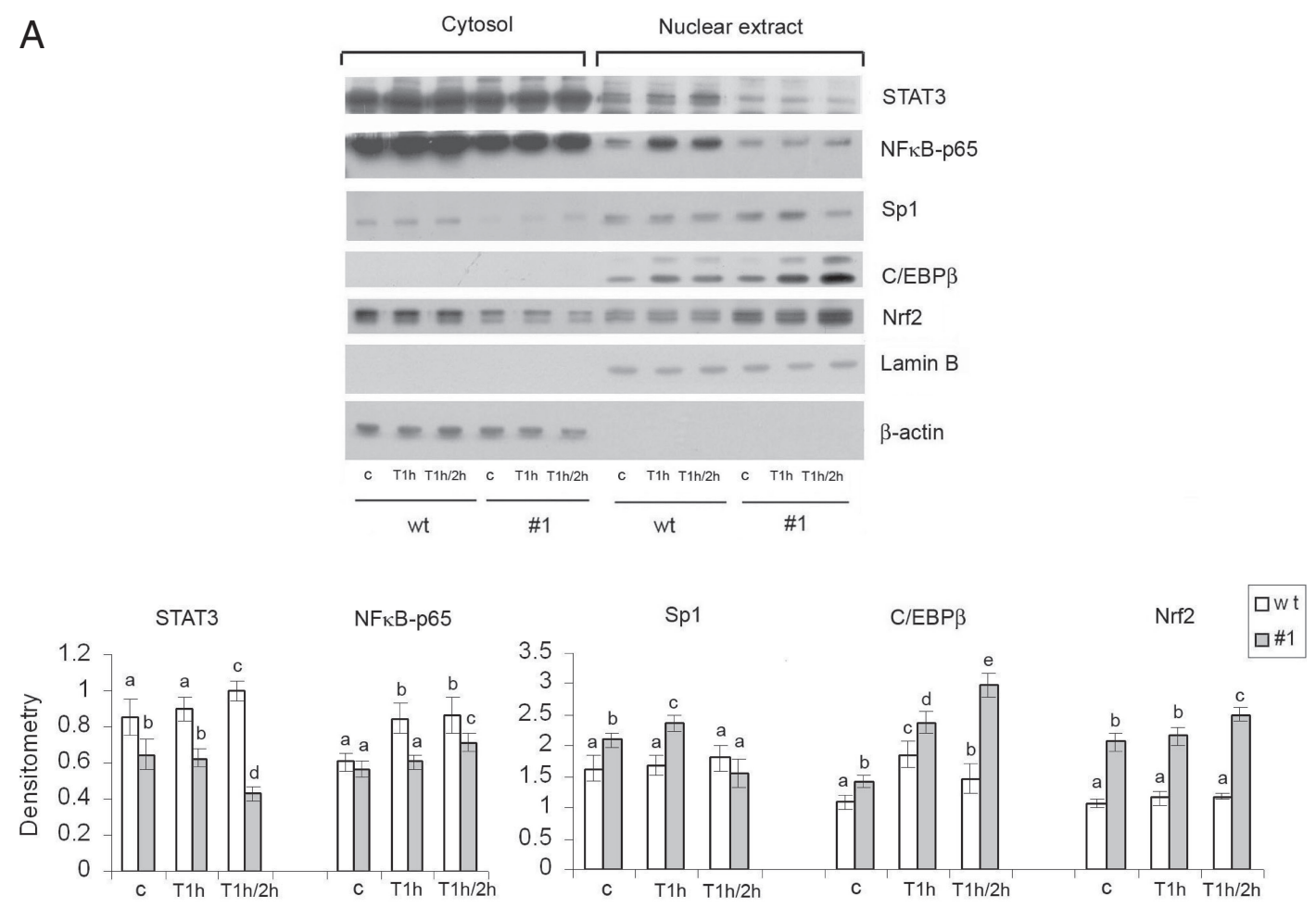

B
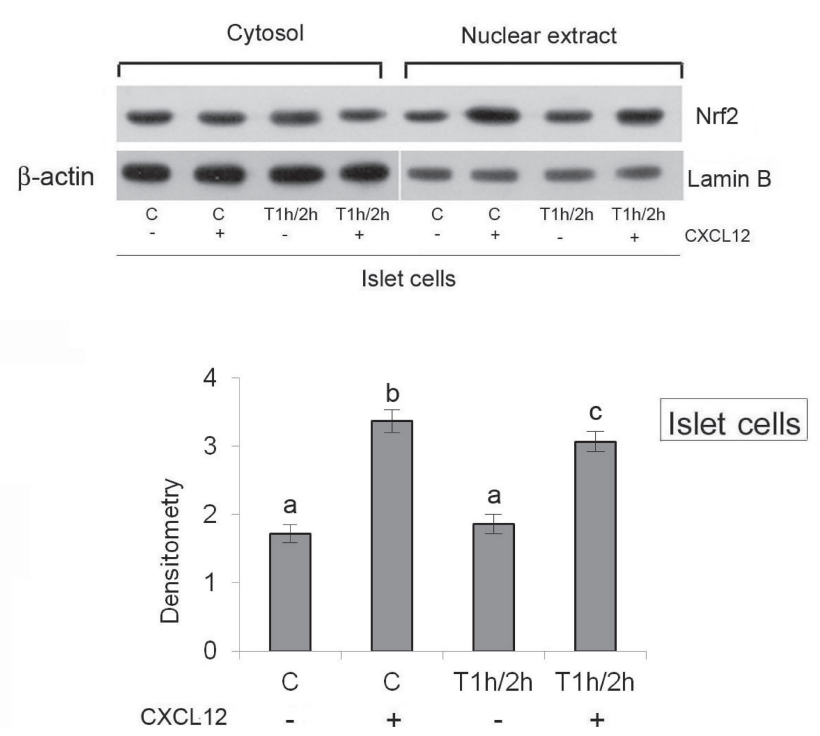

Fig. 5. Enhanced expression of CXCL12 differentially modulates activities of transcription factors in pancreatic cells in the basal state and after $\mathrm{H}_{2} \mathrm{O}_{2}$ treatment. (A) Cellular localization of STAT3, NF $\kappa$ B-p65, Sp1, C/EBP $\beta$ and Nrf2; the transcription factors were analyzed in the cytosolic and nuclear protein fractions of Rin-5F cells. (B) CXCL12-stimulated Nrf2 nuclear translocation in islet cells; Lamin $\mathrm{B}$ and $\beta$-actin served as loading controls for the nuclear and cytosolic fractions, respectively. wt - wild-type Rin-5F; \#1 CXCL12 overexpressing Rin-5F; $(+)$ and $(-)$ - islet cells with or without pretreatment with recombinant CXCL12 $(80 \mathrm{ng} / \mathrm{ml}$; $30 \mathrm{~min}) ; \mathrm{C}-$ control; $\mathrm{T} 1 \mathrm{~h}-\mathrm{H}_{2} \mathrm{O}_{2}\left(\mathrm{IC}_{50}\right)$ treatment for $1 \mathrm{~h} ; \mathrm{T} 1 \mathrm{~h} / 2 \mathrm{~h}-\mathrm{H}_{2} \mathrm{O}_{2}\left(\mathrm{IC}_{50}\right)$ treatment for $1 \mathrm{~h}$, followed by $2 \mathrm{~h}$ recovery in medium. Representative blots from three independent experiments are shown. The results of quantification of immunoreactive bands are presented in the graph showing changes in the nuclear to cytoplasmic ratios of the protein levels relative to the appropriate nuclear (lamin B) and cytosol protein ( $\beta$-actin) loading controls. Results are expressed as means \pm SEM. Means not sharing a common letter are significantly different between groups $(\mathrm{p}<0.05)$. 
A
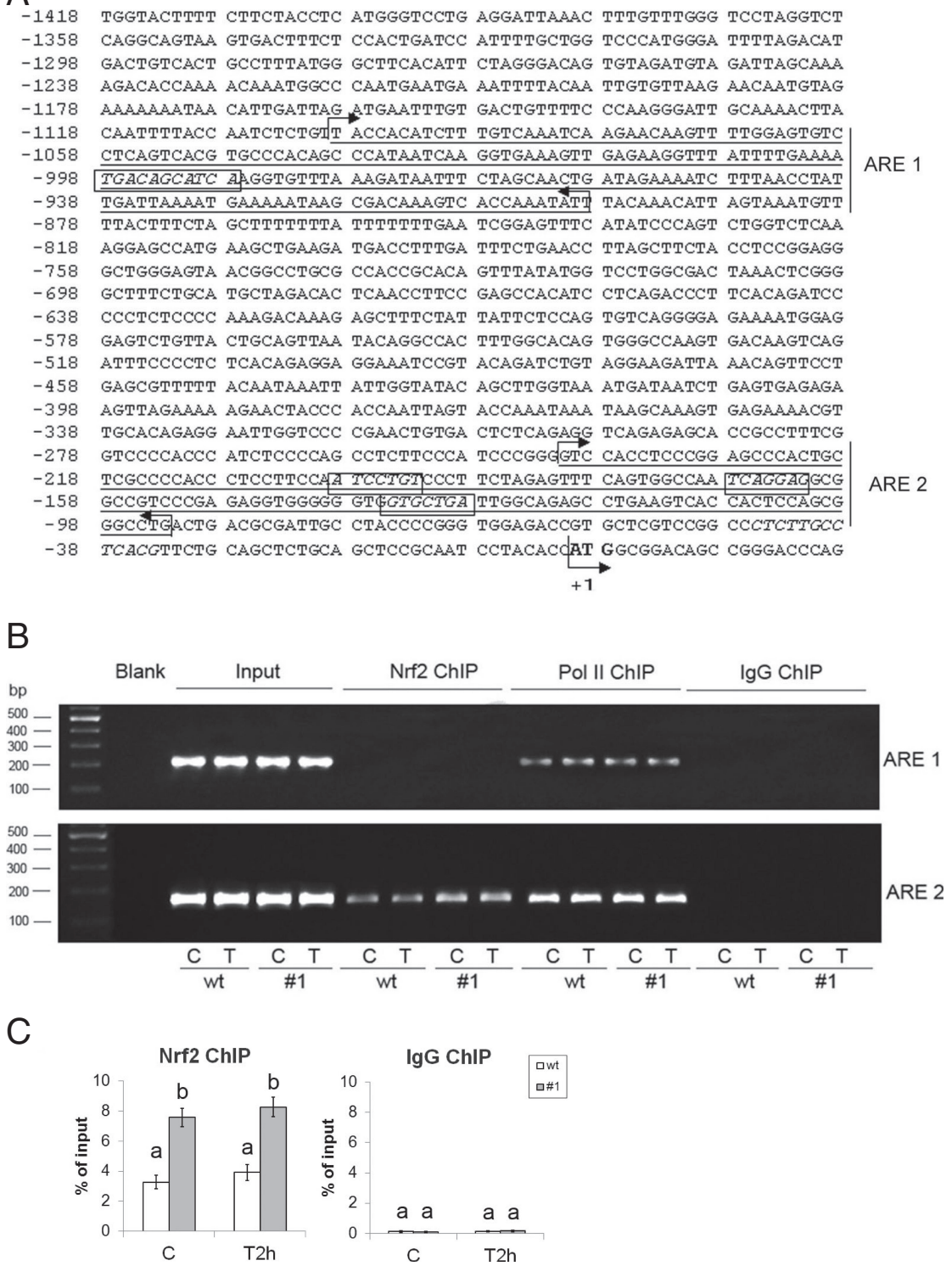

Fig. 6. CXCL12 overexpression enhances Nrf2 binding to the rat CAT gene promoter in the basal state and after $\mathrm{H}_{2} \mathrm{O}_{2}$ treatment in Rin5 F cells. (A) Putative Nrf2 binding sites in the rat CAT gene promoter element $(-1418 /+22 \mathrm{bp})$ were predicted by computer search as described in the Materials and Methods. The Nrf2 and Nrf2/MafK binding sites are in rectangles, the ATG translation start site is in bold (with an arrow, marked as $+1 \mathrm{bp}$ ). Parts of the CAT promoter containing the putative Nrf2 and three Nrf2/MafK binding sequences were annotated as ARE1 and ARE2 regions, respectively, due to their similarity to ARE. The positions of primers used in ChIP analysis are indicated as forward and reverse arrows as follows: the underlined ARE1 region (201 bp) is enclosed with arrows from -1099 (forward arrow) to $-899 \mathrm{bp}$ (reverse arrow) corresponding to forward and reverse primers; the underlined ARE2 region (149 bp) is enclosed with arrows from -241 (forward arrow) to $-93 \mathrm{bp}$ (reverse arrow), which corresponds to the forward and reverse primers, respectively. (B) ChIP assay for Nrf2 binding to the rat CAT promoter analyzed by electrophoresis. Pol II and IgG antibodies were used for ChIP validation. Nrf2 ChIP - DNA from the ChIP assay, probed with Nrf2 antibody; Pol II ChIP - DNA from the ChIP assay, probed with RNA pol II antibody (positive control); IgG ChIP - DNA from the ChIP assay, probed with IgG antibody (negative control); Input (genomic DNA) and Blank (water-only) served as positive and negative controls, respectively, in the PCR reaction; ARE1 - amplicons (201 bp) obtained with primer pairs enclosing the Nrf2-binding site; ARE2 - amplicons (149 bp) obtained with primer pairs enclosing the Nrf2/MafK-binding sites; wt - wild-type Rin-5F; \#1 - CXCL12 overexpressing Rin-5F; C control; $\mathrm{T}$ and $\mathrm{T} 2 \mathrm{~h}$ - cells subjected to $2 \mathrm{~h}$ recovery after $1 \mathrm{~h}$ treatment with an $\mathrm{IC}_{50}$ dose of $\mathrm{H}_{2} \mathrm{O}_{2}$. (C) ChIP assay for Nrf2 binding to the ARE 2 region of the CAT promoter analyzed by RT-qPCR. Average Ct values for Nrf2 samples and IgG controls are expressed as the percentage of the input (\% input). Results are expressed as means \pm SEM. Means not sharing a common letter are significantly different between groups $(\mathrm{p}<0.05)$ 
that contained three putative Nrf2/MafK binding sequences (annotated as the ARE2 region); it did not precipitate the putative Nrf2 binding sequence (annotated as the ARE1 region) within the CAT promoter (Fig. 6B). Quantification of the ChIP assay by RT-qPCR analysis performed with primers for the ARE2 region that contains all three predicted Nrf2/ MafK binding sites revealed that the binding affinity of Nrf2 for ARE2 was significantly higher than control IgG binding (Fig. 6C). The level of control IgG binding affinity for the ARE2 region did not change in wt and \#1 cells, in control conditions and after the $\mathrm{H}_{2} \mathrm{O}_{2}$ treatment. However, Nrf2 binding was higher in \#1 cells than in wt cells; under control conditions it was increased 2.3-fold, and after the $\mathrm{H}_{2} \mathrm{O}_{2}$ treatment it was increased 2.1-fold (Fig. 6C). The binding affinity of Nrf2 for the ARE2 region did not statistically change at $2 \mathrm{~h}$ after initiation of the $\mathrm{H}_{2} \mathrm{O}_{2}$ treatment in either wt or $\# 1$ cells. This result points to a role for Nrf2 in basal transcriptional regulation of CAT. However, we cannot exclude the possibility of increased Nrf2 binding to the CAT promoter at other time points after the $\mathrm{H}_{2} \mathrm{O}_{2}$ treatment.

\section{Discussion}

A growing body of evidence indicates that CXCL12 plays an important role in pancreatic $\beta$-cell survival. In line with its ability to improve the survival and functioning of $\beta$-cells, we reported that CXCL12 promotes a switch of the $\mathrm{H}_{2} \mathrm{O}_{2}$-activated cell death in $\beta$-cells from the necrotic to the apoptotic pathway. ${ }^{19)}$ In the present work, we provide evidence that CXCL12 protects pancreatic $\beta$-cells from the toxic effects of $\mathrm{H}_{2} \mathrm{O}_{2}$ by enhancing CAT activity and expression. We propose that the observed induction of CAT gene expression by CXCL12 was mediated by the activation of Akt, ERK and p38 kinases which are responsible for the phosphorylation/activation of Nrf2 and its nuclear translocation. Consequently, the binding of activated Nrf2 to the CAT gene promoter stimulated CAT expression and activity, contributing to the functional resistance of $\beta$-cells to $\mathrm{H}_{2} \mathrm{O}_{2}$.

$\mathrm{H}_{2} \mathrm{O}_{2}$ exerts its toxic effects by inducing singleand double-strand DNA breaks ${ }^{30}$ ) and through generation of ROS species, such as the hydroxyl radical and singlet oxygen, which cause lipid peroxidation. $^{31)}$ The significantly lower levels of DNA damage and lipid peroxidation in \#1 cells compared to wt cells after $\mathrm{H}_{2} \mathrm{O}_{2}$ treatment reveal that CXCL12 overexpressing \#1 cells possess a higher level of $\mathrm{H}_{2} \mathrm{O}_{2}$ endogenous defense than wt cells. The results presented here indicate that CXCL12 overexpression enhances the resistance of $\beta$-cells to $\mathrm{H}_{2} \mathrm{O}_{2}$ through the induction of CAT which is primarily responsible for $\mathrm{H}_{2} \mathrm{O}_{2}$ elimination. ${ }^{31), 32)}$ The extremely low endogenous CAT activity renders pancreatic $\beta$-cells vulnerable not only to virtually all ROS-producing toxins, but also to $\mathrm{H}_{2} \mathrm{O}_{2}$ produced by $\mathrm{SOD}$ catalyzed reactions. ${ }^{33)}$ Herein we have shown that following $\mathrm{H}_{2} \mathrm{O}_{2}$ treatment, wt cells displayed higher levels of MnSOD and CuZnSOD activities than CXCL12 overexpressing \#1 cells. This could be explained by the lower capacity of wt cells to neutralize $\mathrm{H}_{2} \mathrm{O}_{2}$ provoked ROS generation. Enhanced CAT activity in \#1 cells in the basal state, which was accompanied by lower MnSOD and CuZnSOD activities most likely protected them from the toxic effects of $\mathrm{H}_{2} \mathrm{O}_{2}$.

The constitutively elevated nuclear translocation of STAT3 and NF $\kappa$ B-p65 in wt as compared to $\# 1$ cells could be implicated in the induction of MnSOD gene expression in wt cells. This assumption is in agreement with the STAT3 regulation of constitutive MnSOD gene expression in mouse neuronal cells, ${ }^{34)}$ and its participation in the induction of MnSOD transcription in rat cardiomyocytes. ${ }^{35)} \mathrm{NF} \kappa \mathrm{B}$ responsive elements have been identified in the promoter regions of SOD genes, ${ }^{36), 37)}$ and $\mathrm{NF} \kappa \mathrm{B}$ is a major transcriptional regulator of $\mathrm{MnSOD}$ induction. ${ }^{38), 39)}$ While a role for $\mathrm{NF} \kappa \mathrm{B}$ in $\mathrm{CAT}$ gene regulation has not been determined, the results presented here support the assumption that $\mathrm{NF} \kappa \mathrm{B}$ activation is negatively correlated with CAT expression. ${ }^{40)}$ STAT3 and $\mathrm{NF} \kappa \mathrm{B}$ are activated in response to increased ROS levels, ${ }^{41), 42)}$ and $\mathrm{H}_{2} \mathrm{O}_{2}$-induced activation of $\mathrm{NF} \kappa \mathrm{B}$ has been described. ${ }^{43}$ In contrast to $\# 1$ cells, the $\mathrm{H}_{2} \mathrm{O}_{2}$ treatment promoted an additional increase in STAT3 and NF $\kappa$ B-p65 nuclear translocation in wt cells. This could be explained by the lower capacity of wt cells to eliminate $\mathrm{H}_{2} \mathrm{O}_{2}$. Such an activation of STAT3 and NF $\kappa \mathrm{B}-\mathrm{p} 65$ in wt cells could have contributed to the increase in MnSOD and $\mathrm{CuZnSOD}$ gene expression. In addition, activation of the redox-sensitive transcription factor $\mathrm{NF} \kappa \mathrm{B}$ is a reflection of the higher level of $\mathrm{H}_{2} \mathrm{O}_{2}$-induced oxidative stress in wt cells in comparison to \#1 cells. On the other hand, considering that CXCL12 signaling through CXCR4 activates the JAK2/ STAT3/SOCS3 pathway, the observed decrease in nuclear STAT3 in response to CXCL12 signaling in \#1 cells in comparison to wt cells could result from CXCL12-stimulated SOCS3 upregulation which is a negative feedback regulator of STAT3 activation through direct inhibition of JAK. ${ }^{44), 45)}$ 
The constitutively elevated nuclear levels of Sp1 and $\mathrm{C} / \operatorname{EBP} \beta$, and in particular the increased nuclear translocation of Nrf2 in \#1 cells as compared to wt cells could very likely play an essential role in the high level of constitutive CAT expression and activity in CXCL12 overexpressing cells. This is in agreement with the role $\mathrm{Sp} 1$ plays in the induction of CAT transcription, ${ }^{46)}$ while basal CAT gene expression is regulated by $\mathrm{C} / \operatorname{EBP} \beta .{ }^{47)} \mathrm{We}$ speculate that the $\mathrm{H}_{2} \mathrm{O}_{2}$-promoted increase in nuclear $\mathrm{C} / \mathrm{EBP} \beta$ in wt cells contributed to CAT gene induction. Whereas Sp1 and $\mathrm{C} / \operatorname{EBP} \beta$ contributed to enhanced CAT gene expression in $\# 1$ cells in the basal state, the activation of $\mathrm{Sp} 1$ and $\mathrm{C} / \mathrm{EBP} \beta$ in $\# 1$ cells in response to the $\mathrm{H}_{2} \mathrm{O}_{2}$ treatment points to their important role in the induction of CAT gene expression in response to stress. Considering the role of $\mathrm{Sp} 1$ in constitutive and inducible expression of MnSOD and CuZnSOD, ${ }^{48)}$ it is possible that $\mathrm{Sp} 1$ activation in \#1 cells after the $\mathrm{H}_{2} \mathrm{O}_{2}$ treatment caused the increase in MnSOD and CuZnSOD gene expression. Regarding the involvement of $\mathrm{C} / \mathrm{EBP} \beta$ in the transcriptional regulation of $\mathrm{CuZnSOD},{ }^{49)}$ the $\mathrm{H}_{2} \mathrm{O}_{2}$-promoted induction of CuZnSOD gene expression in wt and \#1 cells could be correlated with $\mathrm{C} / \mathrm{EBP} \beta$ activation.

Nrf2 is negatively regulated by actin-binding protein Keap1 (Kelch-like ECH-associated protein 1), which binds to and sequesters Nrf2 in the cytoplasm, leading to its ubiquitination and proteasome-mediated degradation. $^{50)}$ Obstruction of the Nrf2-Keap1 interaction allows Nrf2 release, nuclear translocation and activation. In the nucleus, Nrf2 dimerizes with proteins such as Jun (c-Jun, Jun-B, Jun-D), c-Fos, Fra1, Nrf1 and small Maf proteins (Musculo aponeurotic fibrosarcoma; MafG, MafK, MafF), forming a transactivation complexes that binds antioxidant response elements (ARE) and participates in the transcriptional activation of antioxidant defense genes. ${ }^{51)}$ Although a Nrf2 binding element has not been identified in the CAT gene promoter, it was shown that Nrf2 positively affects CAT gene expression. ${ }^{43), 52-54)}$ Our results point to an essential role of Nrf2 signaling in increased CAT gene expression in CXCL12 stimulated cells, rendering them more prepared for $\mathrm{H}_{2} \mathrm{O}_{2}$ attack in comparison to control cells. This is in correlation with the findings that the basal level of CAT was significantly lower in Nrf2 knockout cardiac fibroblasts ( $\mathrm{Nrf}^{-/-}$) as compared to Nrf2 expressing wt cells (Nrf2 $\left.\left.{ }^{+/+}\right) .{ }^{52}\right)$ In contrast, the basal levels of SOD and GPx did not differ between $\mathrm{Nrf}_{2}^{+/+}$and $\mathrm{Nrf} 2^{-/-}$cells, suggesting that Nrf2 signaling was not involved in the regulation of the basal expression of these two antioxidative enzymes. Aside from CAT and SOD, Nrf2 targets other genes that could also provide protection to $\beta$ cells from oxidative stress. We therefore examined the mRNA levels of the $\mathrm{H}_{2} \mathrm{O}_{2}$ eliminating enzymes, GPx1 and peroxiredoxin $3(\operatorname{Prdx} 3)$, and of two antioxidant proteins from the phase 2 detoxifying enzyme family, glutathione S-transferase alpha 1 (GSTA1) and heme oxygenase-1 (HMOX-1). These genes were selected in view of their expression in the pancreas and their potential role in $\beta$-cell protection from $\mathrm{H}_{2} \mathrm{O}_{2}$ toxicity. While $\mathrm{GPx} 1$ expression was higher in wt cells than in $\# 1$ cells in control conditions and after the $\mathrm{H}_{2} \mathrm{O}_{2}$ treatment, the expression patterns of Prdx3, GSTA1 and HMOX-1 were similar in both cell lines (results not shown). While further analysis of CXCL12-mediated signaling effects on these proteins is warranted, our preliminary data support the importance of CAT induction in CXCL12-mediated protection of $\beta$-cells from $\mathrm{H}_{2} \mathrm{O}_{2}$-induced stress.

The interaction between Nrf2 and the CAT gene promoter described herein provides evidence for the involvement of Nrf2 in the regulation of CAT gene transcription in rat pancreatic $\beta$-cells. Although the role of small Maf proteins as transcriptional activators is controversial, results obtained using smallMaf-factor-knockout mice support the assertion that small Maf proteins serve as functional heterodimeric partner molecules of Nrf2 in vivo. ${ }^{55)}$ The constitutively higher Nrf2 binding affinity for the CAT gene promoter in $\# 1$ cells than in wt cells that persisted after the $\mathrm{H}_{2} \mathrm{O}_{2}$ treatment, suggests that CXCL12 stimulated Nrf2 activation and Nrf2-mediated induction of CAT.

Activation of CXCL12 downstream kinases could facilitate the transcriptional activation of Nrf2. Namely, Nrf2 nuclear translocation is supported by the activities of several kinases, including ERK, p38, and PI3K/Akt, that have been shown to participate in signal transduction from antioxidants and xenobiotics to the ARE. ${ }^{56)-58)}$ The constitutively higher levels of p-p38, p-ERK and p-Akt in \#1 than in wt cells could contribute to constitutive Nrf2 activity. Although the $\mathrm{H}_{2} \mathrm{O}_{2}$ treatment induced a transient induction of kinases only in wt cells and a slight reduction of kinase phosphorylation in $\# 1$ cells, kinase activity was consistently higher in \#1 cells than in wt cells at all of the analyzed points. The observed higher level of p38 and Akt phosphorylation in CXCL12-pretreated cells when compared to non-pretreated cells, points to the activation of 


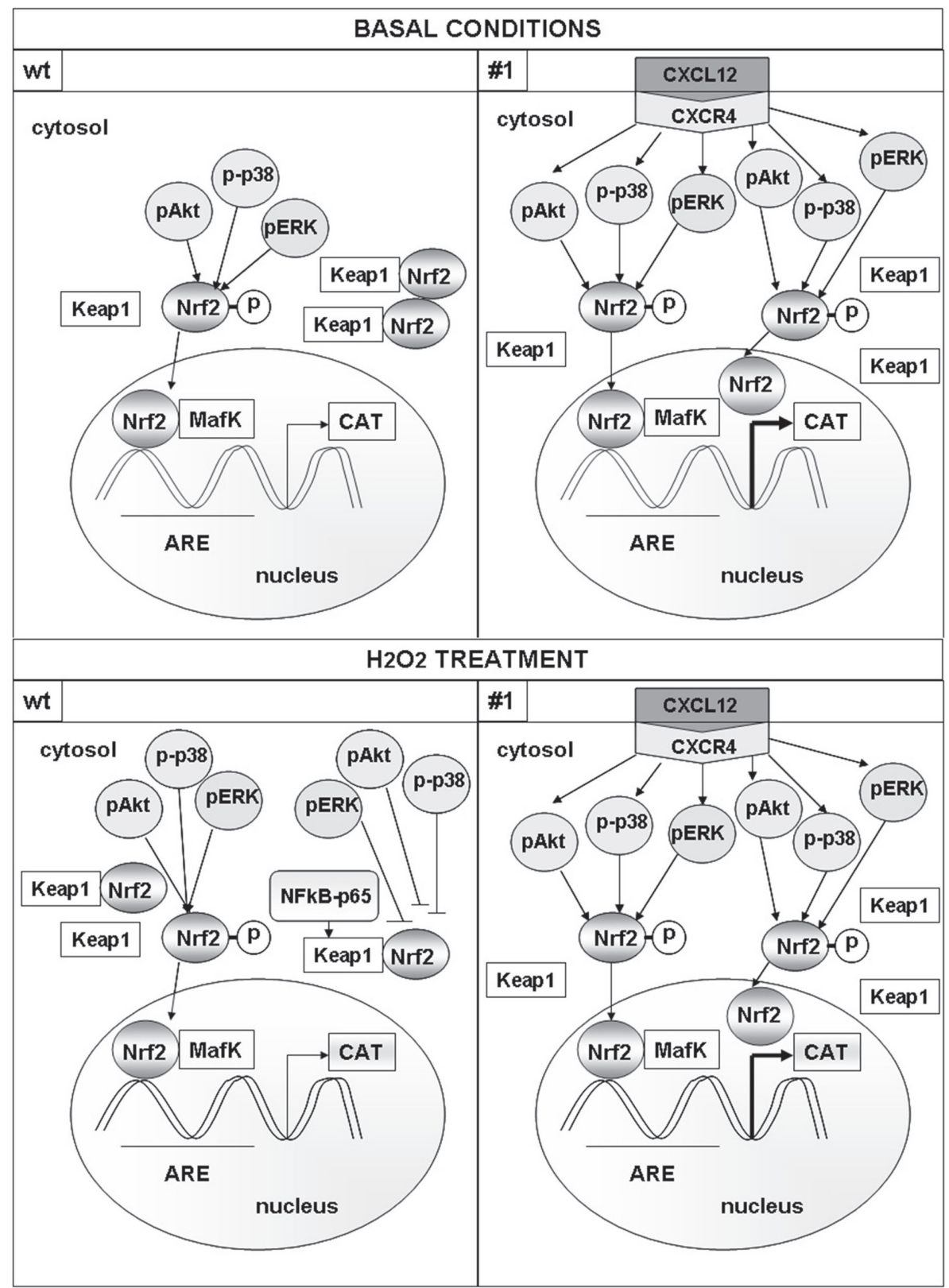

Fig. 7. Proposed mechanism for CXCL12-stimulated Nrf2-ARE-mediated CAT transcription. The two upper panels describe the differences between the regulatory mechanisms that support constitutive CAT expression in wt and \#1 cells (left and right panels, respectively). The lower panels describe the potential mechanisms in oxidative stress, after exposure of wt and \#1 cells (left and right panels, respectively) to $\mathrm{H}_{2} \mathrm{O}_{2}$. Under basal conditions (upper panels), Keap1 targets Nrf2 for ubiquitin-dependent degradation and in this way represses Nrf2-dependent gene expression. In \#1 cells (upper right panel), CXCL12 binding to its receptor CXCR4 activates protein kinases (p38, Akt and ERK) and Nrf2 phosphorylation, inducing nuclear translocation of Nrf2 to a greater extent than in wt cells where the kinase activities are considerably lower. Consequently, in CXCL12-overexpressing \#1 cells, more activated nuclear Nrf2 binds to the CAT gene promoter and maintains higher levels of CAT expression and enzymatic activity than in wt cells. After exposure to $\mathrm{H}_{2} \mathrm{O}_{2}$ (lower left panel), transient induction of p38, Akt and ERK kinases in wt cells was not accompanied by Nrf2 activation. The absence of Nrf2 activation could be attributed to the inhibitory effect of NF $\kappa \mathrm{B}$-p 65 which was more abundant in the cytosol of wt than \#1 cells after $\mathrm{H}_{2} \mathrm{O}_{2}$ treatment. By interacting with Keap1, NF $\kappa$ B-p65 represses Nrf2 dissociation from Keap1 and suppresses the Nrf2-ARE pathway. ${ }^{64)}$ In \#1 cells (lower right panel), the CXCL12 driven increase in nuclear translocation of Nrf2 remained after the $\mathrm{H}_{2} \mathrm{O}_{2}$ treatment probably because of high kinase activity. Nuclear translocation of Nrf2 was not disrupted by the redox-sensitive factor $\mathrm{NF} \kappa \mathrm{B}$-p65. This is probably because of efficient $\mathrm{H}_{2} \mathrm{O}_{2}$ elimination in \#1 cells as a result of the much higher level of basal CAT activity, which results in a lower level of oxidative stress. 
equivalent mechanisms in pancreatic islet cells. These findings point to a potential role of the CXCL12 downstream signaling pathways in Nrf2 activation and increased oxidative stress protection of $\beta$-cells through CAT activation. The improved protection against oxidative stress in $\beta$-cells through CXCL12-mediated Nrf2 activation is in agreement with recent data describing the therapeutic potential of Nrf2 activation as a promising approach to pancreatic $\beta$-cell protection against oxidative damage in diabetes. ${ }^{59)-62)}$

The presented results, together with findings presented previously, strongly suggest that slight stimulation of CAT expression has a positive effect on $\beta$-cells. It provides protection from oxidative stress without impeding insulin secretion. CAT overexpression does not interfere with the glucose responsiveness of insulin-secreting INS-1E cells and rat islets. ${ }^{7)}$ Increased CAT activity in $\beta$-cells of transgenic mice was observed to provide marked protection of their insulin secretion against $\mathrm{H}_{2} \mathrm{O}_{2}$, and significantly reduced the diabetogenic effect of streptozocin (STZ) in vivo. ${ }^{33)}$ On the other hand, strong induction of endogenous antioxidant enzymes in response to oxidative stress may blunt ROS signaling, leading to reduced GSIS. ${ }^{4)}$ Accordingly, it has been shown that exogenously applied CAT to permeable cells inhibits glucose-stimulated $\mathrm{H}_{2} \mathrm{O}_{2}$ accumulation and GSIS. ${ }^{63)}$ These findings suggest that the realization of a balance between $\mathrm{H}_{2} \mathrm{O}_{2}$ production and elimination in $\beta$-cells is critical for their survival, regeneration and proper functioning in diabetes. Therefore, CXCL12-stimulated doubling of CAT expression and activity may have relevant biological consequence in terms of $\beta$-cell protection against $\mathrm{H}_{2} \mathrm{O}_{2}$ induced toxicity and preservation of insulin gene expression in both diabetes types 1 and 2 .

In conclusion, we present a model that describes the increased protection of $\beta$-cells from $\mathrm{H}_{2} \mathrm{O}_{2}$-induced oxidative stress through CXCL12-stimulated CAT expression (Fig. 7). Central to this model is the transduction pathway, which includes CXCL12 stimulation of downstream p38, Akt and ERK kinases, Nrf2 activation and resulting ARE-mediated upregulation of CAT transcription. In addition to the previously described positive effects of CXCL12 on pancreatic $\beta$-cell survival, the results of our study confirm the therapeutic potential of CXCL12 in diabetes treatment. Thus, stimulated expression of CXCL12 could increase CAT expression and activity in $\beta$-cells of diabetic patients and prevent their oxidative damage and ultimate demise.

\section{Acknowledgements}

This work was supported by the Ministry of Education, Science and Technological Development of the Republic of Serbia, Grant No. 173020. We are very grateful to Professor Dr. Ludwig Wagner (Department of Internal Medicine III, Medical University of Vienna, Vienna, Austria) for providing a Rin-5F cells and for all scientific help, suggestions and unlimited support. The authors declare no potential conflict of interest.

\section{References}

1) Lenzen, S. (2008) Oxidative stress: the vulnerable beta-cell. Biochem. Soc. Trans. 36, 343-347.

2) Robertson, R.P., Zhou, H., Zhang, T. and Harmon, J.S. (2007) Chronic oxidative stress as a mechanism for glucose toxicity of the beta cell in type 2 diabetes. Cell Biochem. Biophys. 48, 139-146.

3) Lenzen, S., Drinkgern, J. and Tiedge, M. (1996) Low antioxidant enzyme gene expression in pancreatic islets compared with various other mouse tissues. Free Radic. Biol. Med. 20, 463-466.

4) Pi, J., Zhang, Q., Fu, J., Woods, C.G., Hou, Y., Corkey, B.E., Collins, S. and Andersen, M.E. (2010) ROS signaling, oxidative stress and Nrf2 in pancreatic beta-cell function. Toxicol. Appl. Pharmacol. 244, 77-83.

5) Rhee, S.G. (2006) Cell signaling. $\mathrm{H}_{2} \mathrm{O}_{2}$, a necessary evil for cell signaling. Science 312, 1882-1883.

6) Chen, H., Li, X. and Epstein, P.N. (2005) MnSOD and catalase transgenes demonstrate that protection of islets from oxidative stress does not alter cytokine toxicity. Diabetes 54, 1437-1446.

7) Lortz, S., Gurgul-Convey, E., Naujok, O. and Lenzen, S. (2013) Overexpression of the antioxidant enzyme catalase does not interfere with the glucose responsiveness of insulin-secreting INS-1E cells and rat islets. Diabetologia 56, 774-782.

8) Nti, B.K., Markman, J.L., Bertera, S., Styche, A.J., Lakomy, R.J., Subbotin, V.M., Trucco, M. and Zorina, T.D. (2012) Treg cells in pancreatic lymph nodes: the possible role in diabetogenesis and beta cell regeneration in a T1D model. Cell. Mol. Immunol. 9, 455-463.

9) Teicher, B.A. and Fricker, S.P. (2010) CXCL12 (SDF-1)/CXCR4 pathway in cancer. Clin. Cancer Res. 16, 2927-2931.

10) Tilton, B., Ho, L., Oberlin, E., Loetscher, P., Baleux, F., Clark-Lewis, I. and Thelen, M. (2000) Signal transduction by CXC chemokine receptor 4 . Stromal cell-derived factor 1 stimulates prolonged protein kinase B and extracellular signal-regulated kinase 2 activation in T lymphocytes. J. Exp. Med. 192, 313-324.

11) Badr, G., Al-Sadoon, M.K., El-Toni, A.M. and Daghestani, M. (2012) Walterinnesia aegyptia venom combined with silica nanoparticles enhances the functioning of normal lymphocytes 
through PI3K/AKT, NFkappaB and ERK signaling. Lipids Health Dis. 11, 27.

12) Ward, S.G. (2006) T lymphocytes on the move: chemokines, PI 3-kinase and beyond. Trends Immunol. 27, 80-87.

13) Xia, Z., Dickens, M., Raingeaud, J., Davis, R.J. and Greenberg, M.E. (1995) Opposing effects of ERK and JNK-p38 MAP kinases on apoptosis. Science 270, 1326-1331.

14) Hui, L., Bakiri, L., Stepniak, E. and Wagner, E.F. (2007) p38alpha: a suppressor of cell proliferation and tumorigenesis. Cell Cycle 6, 2429-2433.

15) Thornton, T.M. and Rincon, M. (2009) Non-classical p38 map kinase functions: cell cycle checkpoints and survival. Int. J. Biol. Sci. 5, 44-51.

16) Yano, T., Liu, Z., Donovan, J., Thomas, M.K. and Habener, J.F. (2007) Stromal cell derived factor-1 (SDF-1)/CXCL12 attenuates diabetes in mice and promotes pancreatic beta-cell survival by activation of the prosurvival kinase Akt. Diabetes 56, 2946-2957.

17) Liu, Z., Stanojević, V., Avadhani, S., Yano, T. and Habener, J.F. (2011) Stromal cell-derived factor-1 (SDF-1)/chemokine (C-X-C motif) receptor 4 (CXCR4) axis activation induces intra-islet glucagon-like peptide-1 (GLP-1) production and enhances beta cell survival. Diabetologia 54, 2067-2076.

18) Marković, J., Grdović, N., Dinić, S., KaranDjurašević, T., Uskoković, A., Arambašić, J., Mihailović, M., Pavlović, S., Poznanović, G. and Vidaković, M. (2013) PARP-1 and YY1 are important novel regulators of CXCL12 gene transcription in rat pancreatic beta cells. PLoS One 8, e59679.

19) Grdović, N., Dinić, S., Mihailović, M., Uskoković, A., Arambašić-Jovanović, J., Poznanović, G., Wagner, L. and Vidaković, M. (2014) CXC chemokine ligand 12 protects pancreatic beta-cells from necrosis through Akt kinase-mediated modulation of poly(ADP-ribose) polymerase-1 activity. PLoS One 9, e101172.

20) Ilhan, A., Nabokikh, A., Maj, M., Vidakovć, M., Nielsen, J.H., Prikoszovich, T., Niederle, B., Base, W., Luger, A. and Wagner, L. (2009) CXCL12/ SDF-1 over-expression in human insulinomas and its biological relevance. Mol. Cell. Endocrinol. 298, $1-10$.

21) Nadal, A., Rovira, J.M., Laribi, O., Leon-Guinto, T., Andreu, E., Ripoll, C. and Soria, B. (1998) Rapid insulinotropic effect of 17beta-estradiol via a plasma membrane receptor. FASEB J. 12, 13411348.

22) Ohkawa, H., Ohishi, N. and Yagi, K. (1979) Assay for lipid peroxides in animal tissues by thiobarbituric acid reaction. Anal. Biochem. 95, 351-358.

23) Lowry, O.H., Rosebrough, N.J., Farr, A.L. and Randall, R.J. (1951) Protein measurement with the Folin phenol reagent. J. Biol. Chem. 193, 265275.

24) Misra, H.P. and Fridovich, I. (1972) The role of superoxide anion in the autoxidation of epinephrine and a simple assay for superoxide dismutase.
J. Biol. Chem. 247, 3170-3175.

25) Claiborne, A. (1984) Catalase activity. In Handbook of Methods for Oxygen Radical Research (ed. Greenwald, R.A.). CRC Press Inc., Boca Raton, FL, pp. 283-284.

26) Nakashima, H., Yamamoto, M., Goto, K., Osumi, T., Hashimoto, T. and Endo, H. (1989) Isolation and characterization of the rat catalase-encoding gene. Gene 79, 279-288.

27) Giddings, S.J., Carnaghi, L.R., Fischer, L.J. and Miller, C.P. (1991) Differential regulation of rat insulin I and II messenger RNA synthesis: effects of fasting and cyproheptadine. Mol. Endocrinol. 5, 549-554.

28) Fiedorek, F.T. Jr., Carnaghi, L.R. and Giddings, S.J. (1990) Selective expression of the insulin I gene in rat insulinoma-derived cell lines. Mol. Endocrinol. 4, 990-999.

29) Zhou, Y., Wang, Q., Evers, B.M. and Chung, D.H. (2005) Signal transduction pathways involved in oxidative stress-induced intestinal epithelial cell apoptosis. Pediatr. Res. 58, 1192-1197.

30) Driessens, N., Versteyhe, S., Ghaddhab, C., Burniat, A., De Deken, X., Van Sande, J., Dumont, J.E., Miot, F. and Corvilain, B. (2009) Hydrogen peroxide induces DNA single- and double-strand breaks in thyroid cells and is therefore a potential mutagen for this organ. Endocr. Relat. Cancer 16, 845-856.

31) Chance, B., Sies, H. and Boveris, A. (1979) Hydroperoxide metabolism in mammalian organs. Physiol. Rev. 59, 527-605.

32) Halliwell, B.G. and Gutteridge, J.M.C. (1999) Free Radicals in Biology and Medicine, third ed. Oxford University Press, New York.

33) Xu, B., Moritz, J.T. and Epstein, P.N. (1999) Overexpression of catalase provides partial protection to transgenic mouse beta cells. Free Radic. Biol. Med. 27, 830-837.

34) Jung, J.E., Kim, G.S., Narasimhan, P., Song, Y.S. and Chan, P.H. (2009) Regulation of Mnsuperoxide dismutase activity and neuroprotection by STAT3 in mice after cerebral ischemia. J. Neurosci. 29, 7003-7014.

35) Negoro, S., Kunisada, K., Fujio, Y., Funamoto, M., Darville, M.I., Eizirik, D.L., Osugi, T., Izumi, M., Oshima, Y., Nakaoka, Y., Hirota, H., Kishimoto, T. and Yamauchi-Takihara, K. (2001) Activation of signal transducer and activator of transcription 3 protects cardiomyocytes from hypoxia/reoxygenation-induced oxidative stress through the upregulation of manganese superoxide dismutase. Circulation 104, 979-981.

36) Hoffmann, A., Natoli, G. and Ghosh, G. (2006) Transcriptional regulation via the NF-kappaB signaling module. Oncogene 25, 6706-6716.

37) Xu, Y., Kiningham, K.K., Devalaraja, M.N., Yeh, C.C., Majima, H., Kasarskis, E.J. and St Clair, D.K. (1999) An intronic NF-kappaB element is essential for induction of the human manganese superoxide dismutase gene by tumor necrosis factor-alpha and interleukin-1beta. DNA Cell Biol. 
18, 709-722.

38) Eastgate, J., Moreb, J., Nick, H.S., Suzuki, K., Taniguchi, N. and Zucali, J.R. (1993) A role for manganese superoxide dismutase in radioprotection of hematopoietic stem cells by interleukin-1. Blood 81, 639-646.

39) St Clair, D.K., Porntadavity, S., Xu, Y. and Kiningham, K. (2002) Transcription regulation of human manganese superoxide dismutase gene. Methods Enzymol. 349, 306-312.

40) Schreiber, J., Jenner, R.G., Murray, H.L., Gerber, G.K., Gifford, D.K. and Young, R.A. (2006) Coordinated binding of NF-kappaB family members in the response of human cells to lipopolysaccharide. Proc. Natl. Acad. Sci. U.S.A. 103, 5899-5904.

41) Simon, A.R., Rai, U., Fanburg, B.L. and Cochran, B.H. (1998) Activation of the JAK-STAT pathway by reactive oxygen species. Am. J. Physiol. 275, C1640-C1652.

42) Janssen-Heininger, Y.M., Poynter, M.E. and Baeuerle, P.A. (2000) Recent advances towards understanding redox mechanisms in the activation of nuclear factor kappaB. Free Radic. Biol. Med. 28, 1317-1327.

43) Vaziri, N.D. (2012) Protective effect of Nrf2 and catalase in maternal diabetes-induced perinatal hypertension and kidney disease. Diabetes 61, 2400-2402.

44) Yasukawa, H., Hoshijima, M., Gu, Y., Nakamura, T., Pradervand, S., Hanada, T., Hanakawa, Y., Yoshimura, A., Ross, J. Jr. and Chien, K.R. (2001) Suppressor of cytokine signaling-3 is a biomechanical stress-inducible gene that suppresses gp130mediated cardiac myocyte hypertrophy and survival pathways. J. Clin. Invest. 108, 1459-1467.

45) Ozawa, Y., Nakao, K., Shimazaki, T., Shimmura, S., Kurihara, T., Ishida, S., Yoshimura, A., Tsubota, K. and Okano, H. (2007) SOCS3 is required to temporally fine-tune photoreceptor cell differentiation. Dev. Biol. 303, 591-600.

46) Nenoi, M., Ichimura, S., Mita, K., Yukawa, O. and Cartwright, I.L. (2001) Regulation of the catalase gene promoter by Sp1, CCAAT-recognizing factors, and a WT1/Egr-related factor in hydrogen peroxide-resistant HP100 cells. Cancer Res. 61, $5885-5894$.

47) Taniguchi, M., Hashimoto, M., Hori, N. and Sato, K. (2005) CCAAT/enhancer binding protein-beta (C/EBP-beta), a pivotal regulator of the TATAless promoter in the rat catalase gene. FEBS Lett. 579, 5785-5790.

48) Miao, L. and St Clair, D.K. (2009) Regulation of superoxide dismutase genes: implications in disease. Free Radic. Biol. Med. 47, 344-356.

49) Seo, S.J., Kang, S.S., Cho, G., Rho, H.M. and Jung, G. (1997) C/EBP alpha and C/EBPbeta play similar roles in the transcription of the human $\mathrm{Cu}$ / Zn SOD gene. Gene 203, 11-15.

50) Itoh, K., Wakabayashi, N., Katoh, Y., Ishii, T., O'Connor, T. and Yamamoto, M. (2003) Keap1 regulates both cytoplasmic-nuclear shuttling and degradation of Nrf2 in response to electrophiles. Genes Cells 8, 379-391.

51) Itoh, K., Chiba, T., Takahashi, S., Ishii, T., Igarashi, K., Katoh, Y., Oyake, T., Hayashi, N., Satoh, K., Hatayama, I., Yamamoto, M. and Nabeshima, Y. (1997) An Nrf2/small Maf heterodimer mediates the induction of phase II detoxifying enzyme genes through antioxidant response elements. Biochem. Biophys. Res. Commun. 236, 313-322.

52) Zhu, H., Itoh, K., Yamamoto, M., Zweier, J.L. and Li, Y. (2005) Role of Nrf2 signaling in regulation of antioxidants and phase 2 enzymes in cardiac fibroblasts: protection against reactive oxygen and nitrogen species-induced cell injury. FEBS Lett. 579, 3029-3036.

53) Dreger, H., Westphal, K., Weller, A., Baumann, G., Stangl, V., Meiners, S. and Stangl, K. (2009) Nrf2dependent upregulation of antioxidative enzymes: a novel pathway for proteasome inhibitor-mediated cardioprotection. Cardiovasc. Res. 83, 354361.

54) Aminzadeh, M.A., Nicholas, S.B., Norris, K.C. and Vaziri, N.D. (2013) Role of impaired Nrf2 activation in the pathogenesis of oxidative stress and inflammation in chronic tubulo-interstitial nephropathy. Nephrol. Dial. Transplant. 28, 20382045.

55) Motohashi, H., Katsuoka, F., Engel, J.D. and Yamamoto, M. (2004) Small Maf proteins serve as transcriptional cofactors for keratinocyte differentiation in the Keap1-Nrf2 regulatory pathway. Proc. Natl. Acad. Sci. U.S.A. 101, 6379-6384.

56) Zipper, L.M. and Mulcahy, R.T. (2000) Inhibition of ERK and p38 MAP kinases inhibits binding of Nrf2 and induction of GCS genes. Biochem. Biophys. Res. Commun. 278, 484-492.

57) Lee, J.M., Hanson, J.M., Chu, W.A. and Johnson, J.A. (2001) Phosphatidylinositol 3-kinase, not extracellular signal-regulated kinase, regulates activation of the antioxidant-responsive element in IMR-32 human neuroblastoma cells. J. Biol. Chem. 276, 20011-20016.

58) Rojo, A.I., Sagarra, M.R. and Cuadrado, A. (2008) GSK-3beta down-regulates the transcription factor Nrf2 after oxidant damage: relevance to exposure of neuronal cells to oxidative stress. J. Neurochem. 105, 192-202.

59) Song, M.Y., Kim, E.K., Moon, W.S., Park, J.W., Kim, H.J., So, H.S., Park, R., Kwon, K.B. and Park, B.H. (2009) Sulforaphane protects against cytokine- and streptozotocin-induced beta-cell damage by suppressing the NF-kappaB pathway. Toxicol. Appl. Pharmacol. 235, 57-67.

60) Bhakkiyalakshmi, E., Shalini, D., Sekar, T.V., Rajaguru, P., Paulmurugan, R. and Ramkumar, K.M. (2014) Therapeutic potential of pterostilbene against pancreatic beta-cell apoptosis mediated through Nrf2. Br. J. Pharmacol. 171, 1747-1757.

61) Uruno, A., Furusawa, Y., Yagishita, Y., Fukutomi, T., Muramatsu, H., Negishi, T., Sugawara, A., Kensler, T.W. and Yamamoto, M. (2013) The Keap1-Nrf2 system prevents onset of diabetes 
mellitus. Mol. Cell. Biol. 33, 2996-3010.

62) Yagishita, Y., Fukutomi, T., Sugawara, A., Kawamura, H., Takahashi, T., Pi, J., Uruno, A. and Yamamoto, M. (2014) Nrf2 protects pancreatic beta-cells from oxidative and nitrosative stress in diabetic model mice. Diabetes 63, 605-618.

63) Pi, J., Bai, Y., Zhang, Q., Wong, V., Floering, L.M., Daniel, K., Reece, J.M., Deeney, J.T., Andersen, M.E., Corkey, B.E. and Collins, S. (2007) Reactive oxygen species as a signal in glucose-stimulated insulin secretion. Diabetes 56, 1783-1791.

64) Yu, M., Li, H., Liu, Q., Liu, F., Tang, L., Li, C., Yuan, Y., Zhan, Y., Xu, W., Li, W., Chen, H., Ge, C., Wang, J. and Yang, X. (2011) Nuclear factor p65 interacts with Keap1 to repress the Nrf2-ARE pathway. Cell. Signal. 23, 883-892.

(Received Jan. 26, 2016; accepted Sep. 1, 2016) 